\title{
$30-31,40-52,70$ \\ Courting Risk:

Disability, Masculinity, and Liability

on Iowa's Railroads, 1868-1900

\section{JOHN WILLIAMS-SEARLE}

SEPTEMBER 9, 1868, should have been just another day for Edward Laughlin. The twenty-one-year-old brakeman had worked for the Dubuque \& Sioux City Railroad-part of the Illinois Central-for five years. His employer regarded him as "a good industrious man, and a skillful brakeman," claiming that "no man ... had a better prospect of promotion." ${ }^{11}$ On this day, however, as he attempted to couple two freight cars to a mail car at the Ackley, Iowa, station, something went horribly wrong. After riding the cars down a grade to the mail car, Laughlin hopped off and ran ahead to make the coupling. Ideally, the bumpers on the end of the cars should have met with a gentle thump, allowing Laughlin to slip between to insert the coupling link and drop the pin. It was a risky business, but he had coupled thousands of cars and thought he could time his move precisely. On this night, however, the cars were rolling too quickly. As he darted between them, the cars slammed together, their bumpers misaligned, and their platforms collided. Laughlin screamed as the end of the brake rod jammed into his stomach. He hung there, crushed and impaled. In less than a second, Laughlin had joined the ranks of the disabled railroader. ${ }^{2}$

I would like to thank Shelton Stromquist, Bridgett Williams-Searle, and four anonymous readers for their comments and assistance. The research contained herein was supported by funding received from the State Historical Society of Iowa and the Newberry Library, Chicago.

1. Appellant's Abstract of Record at 1 and 15, Muldowney v. Illinois Central Ry. Co., 36 Iowa 462 (1873).

2. Ibid., 4-7, 14-15.

THE ANNALS OF IOWA 58 (Winter 1999). CThe State Historical Society of Iowa, 1999. 
As rail use and track mileage in the United States grew during the Gilded Age, so too did the number of railroad workers killed and injured on the job. ${ }^{3}$ In 1889, the first year the Interstate Commerce Commission (ICC) compiled national statistics on accidents, railroad companies reported that one out of every 375 employees had been killed in the previous year, while one out of 35 had been injured. An unknown number suffered from unreported injuries. Locomotive engineers, firemen, conductors, and brakemen faced an even greater risk of harm. Of the men employed directly in these "running trades," known collectively as trainmen, one out of every 117 had been killed; one in every 12 was injured. ${ }^{4}$ Commentators reached for metaphors of war to describe the carnage. In 1892 Congressman Henry Cabot Lodge drew a direct parallel between employee accidents and war casualties. "The object of trainmen is to carry on safely the railway traffic of a great country. Yet they suffer as if they were fighting a war, and the percentage of loss to numbers employed, if not so high as with soldiers, is frightful enough." ${ }^{5}$

Edward Laughlin, like the thousands of others who fell on a battleground of rails and ties, had few resources with which to sustain himself. How did Laughlin and his comrades in arms, most too young to withdraw from the work force, cope with the economic, legal, and emotional ramifications of work-related injury? Although industrial capitalism created broken bodies almost as efficiently as it created market goods, historians are not yet prepared to answer that question. Crystal Eastman first articulated the complex interlinkage of technology, safety, dis-

3. In 1860 the United States contained 30,626 miles of track; by 1890 , this number had risen to 166,703 miles, and by 1900 to 193,346 miles. Maury Klein, Unfinished Business: The Railroad in American Life (Hanover, NH, 1994), 13, 21.

4. These company-authored reports probably grossly underestimated the number of injuries. Expressed in whole numbers, 1,972 railroaders were killed and 20,028 were injured on the job in 1889 . U.S. Interstate Commerce Commission, Second Annual Report on the Statistics of Railways in the United States to the Interstate Commerce Commission for the Year Ending June 30, 1889 (Washington, DC, 1890), 36-38; Walter Licht, Working for the Railroad: The Organization of Work in the Nineteenth Century (Princeton, NJ, 1983), 190.

5. Henry Cabot Lodge, "A Perilous Business and the Remedy," North American Review 154 (1892), 191. 
ability, law, and masculinity in $1910 .{ }^{6}$ Yet subsequent scholars have impeded a coherent understanding of occupational disability by treating each of those issues as a separate category of inquiry. For example, works about railroad safety emphasize technology or management policies, ignoring the workers for whom safety was a life or death issue. In reality, however, railroad workers' attempts to cope with risk and disability, like management policies, both preceded technological advancements and changed in response to technological and legal developments. Books on workplace casualties, meanwhile, approach the problem from the perspective of industrial medicine. Medical historians treat afflicted workers as statistical aggregates, failing to examine how responses to injury were shaped by workers' understandings of the ideological relationships between risk, gender, disability, and capitalism. ${ }^{8}$ Legal historians address developments in tort law but divorce the evolution of legal wisdom from the context of the workplace.' Finally,

6. See Crystal Eastman, Work Accidents and the Law, The Pittsburgh Survey, vol. 2 (New York, 1910). Eastman's work, long neglected, should serve as a theoretical starting point for the study of occupational disability.

7. Charles Hugh Clark, "The Railroad Safety Movement in the United States: Origins and Development, 1869 to 1893 " (Ph.D. diss., University of Illinois, 1966); Steven W. Usselman, "Air Brakes for Freight Trains: Technological Innovation in the American Railroad Industry, 1869-1900," Business History Review 58 (1984), 30-50; and, to a lesser extent, Mark Aldrich, Safety First: Technology, Labor, and Business in the Building of American Work Safety, 1870-1939 (Baltimore, 1997), chaps. 1 and 5. For management responses to the safety crisis, see Kurt Wetzel, "Railroad Management's Response to Operating Employees Accidents, 1890-1913," Labor History 21 (1980), 351-68.

8. See T. Lyle Hazlett and William W. Hummel, Industrial Medicine in Western Pennsylvania, 1850-1950 (Pittsburgh, 1957); Martin Cherniack, The Hawk's Nest Incident: America's Worst Industrial Disaster (New Haven, CT, 1986); Jacqueline Karnell Corn, Response to Occupational Health Hazards: A Historical Perspective (New York, 1992); and Christopher C. Sellers, Hazards of the Job: From Industrial Disease to Environmental Health Science (Chapel Hill, NC, 1997). For two important exceptions, see David Rosner and Gerald Markowitz, Deadly Dust: Silicosis and the Politics of Occupational Disease in Twentieth-Century America (Princeton, NJ, 1991); and Alan Derickson, Black Lung: Anatomy of a Public Health Disaster (Ithaca, NY, 1998).

9. In an important departure from the general treatment of accident law, John Fabian Witt argues that workers' desire to control their workplaces actually hindered workers' compensation reform in the nineteenth century. Corporations, he contends, avoided accident liability by endorsing the notion that workers should assume all responsibility for workplace safety; management 
trainmen's changing perceptions of risk and disability were colored by their views on manliness, worker control, and personal responsibility. Although labor historians have demonstrated that male workers' constructions of class identity were situated in a particular conception of manhood, historians of American manhood have usually ignored the class content of masculine ideals. ${ }^{10}$ Historians of disability, likewise, suggest that people with disabilities serve as an embodied "other" against which "normal" male and female bodies and lives are evaluated, but few labor historians apply that insight when they theorize about worker-management relations or manhood. ${ }^{11}$ Each subset of scholars has felt a different part of the elephant; none has fully described its essence. ${ }^{12}$

and workers agreed that injury was an indication of moral failing or negligence on the part of the injured. By the end of the nineteenth century, however, workers surrendered some aspects of job control in exchange for an acknowledgment of corporate liability in accident cases. See "The Transformation of Work and the Law of Workplace Accidents, 1842-1910," Yale Law Journal 107 (1998), 1467-1502.

10. Although the term manhood is usually missing, David Montgomery, Workers' Control in America (New York, 1979), argues that skilled craftsmen tried to maintain their autonomy in the workplace as managers attempted to undermine craftsmen's self-direction. Subsequent historians have demonstrated that this battle for autonomy was fought on gendered terrain. See Joshua B. Freeman, "Hardhats: Construction Workers, Manliness, and the 1970 Pro-War Demonstrations," Journal of Social History 26 (1993), 725-44; Alice Kessler-Harris, "Treating the Male as 'Other': Redefining the Parameters of Labor History," Labor History 34 (1993), 190-204; Ava Baron, ed., Work Engendered: Toward a New History of American Labor (Ithaca, NY, 1991); Nick Salvatore, Eugene V. Debs: Citizen and Socialist (Urbana and Chicago, 1982); Robert E. Weir, Beyond Labor's Veil: The Culture of the Knights of Labor (University Park, PA, 1996); and David R. Roediger, The Wages of Whiteness: Race and the Making of the American Working Class (New York, 1991). For works on manhood that ignore class-based constructions of masculinity, see Michael Kimmel, Manhood in America: A Cultural History (New York, 1996); and E. Anthony Rotundo, American Manhood: Transformations in Masculinity from the Revolution to the Modern Era (New York, 1993).

11. See Lennard J. Davis, Enforcing Normalcy: Disability, Deafness, and the Body (New York, 1995); and Susan Wendell, "Toward a Feminist Theory of Disability," Hypatia 42 (1989), 104-22.

12. The best recent effort at making a coherent whole out of these approaches is Alan Derickson, Workers' Health, Workers' Democracy: The Western Miners' Struggle, 1891-1925 (Ithaca, NY, 1988). Derickson argues that the Western Federation of Miners grappled with the constant threat and reality of injury and disability through health and welfare programs designed to defeat the un- 
Historical research on occupational disability, therefore, is in need of a unified theoretical approach. The study of disability, properly considered, transects the histories of labor, business, medicine, law, reform, public policy formation, and gender relations. Male workers conceived manliness largely in terms of bodily wholeness and economic independence. Accordingly, they constructed their ideals of manhood not only in opposition to women, but also in opposition to the feminized, dependent, disabled male. Discourses of masculinity and disability shaped each other, profoundly affecting the ways workers managed risk and addressed safety concerns. During the Gilded Age, moreover, public and corporate policies on the treatment of disabled workers were shaped not only by the availability and affordability of safety technologies, but also by workers' responses to safety issues. The struggle for safer work sites, carried on in courtrooms and legislative chambers as well as on the job, thus became a front in the battle to define the relationship among workers, management, and the state.

Iowa provides an excellent venue in which to explore the broad historical significance of occupational disability in American society. A variety of sources reveal that Iowa's disabled railroaders faced profound hindrances to recovery (either physical or financial) during the Gilded Age. Several major railroads employed Iowa workers. Each of those companies kept meticulous records of their dealings with injured workers as well as of their respective safety policies. Moreover, Iowa courts frequently heard cases concerning railroaders' accidents, providing abundant evidence of changing attitudes toward disabled workers in the workplace and in court. Not all of Iowa's railroaders were members of the railroad brotherhoods that represented the interests of trainmen, but those associations were strong enough to help shape the terms of the emerging debate over safety, disability, and corporate responsibility in Iowa. Worker organizations (such as the Cedar Rapids-based

sympathetic dictates of the mining companies. With an increased awareness of gender as a category of analysis, Derickson's work should provide a template for future historians who wish to integrate the study of risk, safety, disability, manliness, and labor. 
Order of Railway Conductors) combined efforts with safety advocates (such as Iowa Railroad Commissioner Lorenzo S. Coffin) to fight for passage of the Iowa Safety Appliance Act (1890). That measure, which required railroads to install lifesaving technology, became a model for national safety legislation. ${ }^{13}$ In some ways, Iowa offers a glimpse of the best-case scenario for American trainmen in the late nineteenth century, for events in Iowa often served as a lead indicator of national trends. On the other hand, the substantial challenges that even Iowans such as Edward Laughlin faced also exemplify the difficult situation that disabled workers across the nation confronted.

EDWARD LAUGHLIN shared the circumstances of other disabled trainmen of his day. An in-depth examination of his case helps to provide a sense of the interconnections between disability, corporate benevolence, and liability law. Laughlin survived his catastrophic accident. In a few days, he was moved to Dunleith, Illinois, near Dubuque, where his mother, stepfather, and some neighbors cared for him. After a few weeks of bed rest, he walked outdoors with a cane. His chances for recovery seemed bright. By early November, however, his condition had worsened and he was again confined to bed. His suffering became unendurable. He writhed from continuous abdominal pain; his ulcers needed daily lancing. A neighbor, Mrs. Dugan, stated, "Many times he would stuff his handkerchief into his mouth to keep himself from screaming." Because the accident had crushed Laughlin's intestines, he excreted through a hole in his back. Understandably, the turnover rate among his nurses was high. A friend from Dunleith described the scene. "The smell was so bad I could not stand it. I had to go out doors several times. I do not know what it was worth to nurse him. I would not have done it at any price." Even his mother remarked, "There was no end to the offensiveness of it." Although the initial prognosis had been favorable, the damage to Laughlin's intestines prevented his body from ab-

13. See Lorenzo S. Coffin, "Safety Appliances on the Railroads," Annals of Iowa 5 (1903), 561-82. 
sorbing nutrients. Weeks passed and Laughlin dwindled. As Mrs. Dugan later testified, "There was no flesh on him. ${ }^{\text {"14 }}$

What kind of financial and social support might Edward Laughlin have expected as he and his family grappled with the new realities of his disability? If Laughlin had been injured a decade earlier, his employer, the Illinois Central (IC), might have responded differently to his misfortune. During the $1850 \mathrm{~s}$ and early 1860 s, the IC had often paid hospital and funeral expenses for its employees. In the mid-1860s, the line had also required its employees to carry accident insurance, the first railroad to do so. Employees automatically became members of the Illinois Central Relief Club, forfeiting 0.5 percent of their pay to support the plan. Trainmen, however, objected to compulsory enrollment and resented that company officers controlled disbursements. After four years of protests, officials made the plan voluntary. Membership immediately plummeted, and the experiment quietly expired. ${ }^{15}$ If Laughlin had expected the IC to aid him through a rationalized employee welfare plan, he would have been out of luck.

Laughlin still might have hoped for company aid, however. If a railroad manager thought that the injured worker was worthy and might return to useful service, he might attempt to help. ${ }^{16}$ Widows sometimes won employment for a younger son in the place of an injured brother or father so that the family in-

14. Appellant's Abstract of Record at 16-17, Muldowney v. Illinois Central Ry. Co.

15. David L. Lightner, Labor on the Illinois Central Railroad, 1852-1900: The Evolution of an Industrial Environment (New York, 1977), 128-29. The IC Relief Club had failed by the time Edward Laughlin was injured in 1868. In fact, the IC completely reversed its position on company-sponsored welfare schemes during the remainder of the nineteenth century. In 1889, when the Interstate Commerce Commission questioned railroad corporations about employeeemployer relations, C. A. Beck, general manager of the IC, responded that the company had no employee insurance fund. Moreover, their workers had to depend on accommodations provided by the Young Men's Christian Association rather than company-sponsored reading rooms or lodges. U.S. Interstate Commerce Commission, "Relations Existing Between Railway Corporations and Their Employees, Third Annual Report . . ., 1889 (Washington, DC, 1890), 358 (hereafter cited as ICC, Report, 1889). For a celebratory history of the Railroad YMCA, see John F. Moore, The Story of the Railroad "Y" (New York, 1930).

16. In 1856, for example, IC division superintendent James C. Clarke agreed to pay the medical expenses of an injured brakeman who was "a poor boy without friends or money." Lightner, Labor on the Illinois Central Railroad, 124. 
come remained constant. ${ }^{17}$ Company officers always stressed that gratuities or favors did not indicate liability and that only faithful employees would be compensated. For example, after three of conductor F. Clark's toes froze while he cleared the Chicago, Burlington, and Quincy Railroad (CB\&Q) tracks near Keokuk during a severe snowstorm in 1885, Clark was off work for eight weeks and lost \$145.35 in wages. Assistant general manager Henry B. Stone argued that although the line paid "trainmen for taking chances of exposure to the weather," Clark should be given seventy-five dollars. The superintendent of the Iowa lines, W. F. Merrill, agreed, explaining that rewarding Clark for meritorious service would inspire other employees. Clark's "reward" amounted to half pay and did not include the payment of doctor bills; its effect on morale is unknown.

Company benevolence came at a price. Men who wanted aid usually had to waive their right to sue, and companies were not above taking advantage of workers who did not understand the waiver's contents. For example, E. B. Jessup's leg was crushed in a coupling accident on the Chicago and North Western in 1884. After doctors amputated Jessup's foot, a company officer promised him work as a fireman when he recovered. Jessup then unwittingly signed a release, thinking that it was merely a receipt for services provided by the company. When Jessup later arrived in Eagle Grove, Iowa, to claim his promised job, he was told that there was no position available. Jessup then sued, claiming that the company had reneged and insisting that the excruciating pain of his injuries had made it impossible for him to read the waiver. The trial transcript reveals, however, that Jessup was illiterate even under the best of circumstances. Jessup's case demonstrates not only that company representatives sometimes duped workers into signing waivers, but also that company promises were notoriously unreliable. ${ }^{19}$

\section{7. lbid., 127.}

18. W. F. Merrill to Henry B. Stone, 30 April 1885, L. O. Goddard In-Letters: Miscellaneous, 1882-1896, Gratuities, CBQ 3G5.3, Chicago, Burlington, and Quincy Archives, Newberry Library, Chicago; Henry B. Stone to T. J. Potter, 4 May 1885, ibid.; O. E. Stewart to W. F. Merrill, 27 April 1885, ibid.

19. Appellant's Abstract of Record at 1-3, Jessup v. Chicago \& Northwestern Railway Company, 82 Iowa 243 (1891). 
Edward Laughlin's family, therefore, faced a dilemma if they hoped for aid from the IC. If Edward signed a waiver, he and his family would have to rely on unpredictable corporate charity. If he refused to sign, or signed and then attempted to sue, all company aid would stop. Moreover, management reserved its full legal wrath for men who exhibited "ingratitude" and "disloyalty" by seeking to recover full wages and the costs of medical treatment through the courts.

Of course, disabled workers did have other options, depending on the extent of their injuries. If Laughlin's disability had been less severe, he might have hoped (as E. B. Jessup did) for job reassignment. Managers sometimes put disabled trainmen to work at the less demanding jobs of flagmen and watchmen, jobs that able-bodied railroaders scorned. The CB\&Q, for example, reserved work on the Chariton branch for old and disabled trainmen. ${ }^{20}$ Disabled men might also work in companyestablished employee reading rooms. The Pennsylvania Railroad, for example, hired John Freed, an employee who had "lost a leg in the service of the company," to supervise the library at the company's railroad clubhouse in New York. ${ }^{21}$ Despite managerial insistence that the companies' actions should be understood as acts of charity, workers continued to interpret gratuities and job preferences as a matter of justice. ${ }^{22}$

Laughlin, too seriously injured to merit reassignment, initially accepted aid from the IC. The company continued to pay his salary for six months after the accident, an unusually generous stipend. Then the money stopped. Medical expenses mounted; his medicine alone cost four hundred dollars, or as

20. O. H. Kirkpatrick, Working on the Railroad (Philadelphia, 1949), 117; Licht, Working for the Railroad, 202; James H. Ducker, Men of the Steel Rails: Workers on the Atchison, Topeka, and Santa Fe Railroad, 1869-1900 (Lincoln, NE, 1983), 44.

21. "A Railroad Club House," Locomotive Engineers' Monthly Journal 24 (1890), 634; Ducker, Men of the Steel Rails, 44-45.

22. Injured trainmen also relied on their coworkers to pass the hat. Such collections for injured workers were known as "papers." All grades of employees, including railroad officers, subscribed to the frequently circulating papers. Some railroad officials recognized that their contributions could raise morale while narrowing the social divide between workers and managers. For one example, see James O. Fagan, The Autobiography of an Individualist (Boston, 1912), 134-35. 


\section{四 Marks' Patent Artificial Limbs 圆}

\section{WITH RUBBER HANDS AND FEET}

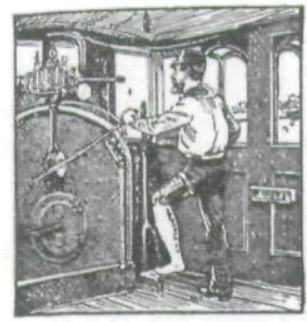

Are natural in action, noisless in motion and the most durable in construction. The accompanying engravings are taken from life and show that persons wearing one or two artificial limbs are able, to engage in every occupation in its fullest capacity.

The engineer wearing an artificial leg, the conductor and bag. gagemaster each wearing a pair of artificial legs with rubber feet, and the ticket agent stamping tickets with an artificial arm, represent a few of the employments engaged in by persons wearing legs and Purchased by the Ir.

United States and many Foreign Governments, the

Atchison, Topeka \& Santa Fe R. R. Ass'n. Baltimore \& Ohio R. R. Ass'n.

Boston \& Albany Ry. Boston \& Maine Ry.

Burlington \& Missouri $\mathrm{R}$. K.

Central New England

\& Western R. R.

Central R. R. of New Jersey.

Chesapeake \& Obio R. R.

Charleston \& Savannah R.R.

Cincinnati \& Muskingum R. R

Chicago, Cincinnati \& St. Louis R. R.

Continental Steamboat Co.

Delaware, Lackawanna \& Western R. R.

Delaware \& Hudson R. R.

Florida Railway \& Navigation Co.

Galveston, Harrisburgh \& San Antonio R. R.

Guatemala Central R. R. in Central America.

Lehigh Valley R. R.

Long Island $R$. $R$.

London \& Northwestern R. R. in Engla nd.

Manhattan Eleva:ed R. R.

Metropolitan S. S. Co.

New York \& Northern R. R.

New York, New Haven \& Hartford R. R.

New York \& Harlem R. R.

Norfolk \& Western R. R.

Old Dominion S. S. Co.

Panama R. R. in South America.

Pennsylvania R. R.

Pbiladelphia \& Reading R. R.

Pittsburg, Cincinnati, Chicago \& St. Louis R'y

Red Star Line S. S. Co.

Richmond \& Danville R. R.

South Bound R, R.

St, Louis, Arkansas \& Texas R. R.

Union Pacific System.

West Jersey R. R.

And other transportation lines.

\section{OVER 13,000 IN USE,}

Scattered in all parts of the world.

Eminent surgeons and competent judges 3. commend the rubber foot and hand for their many advantages.
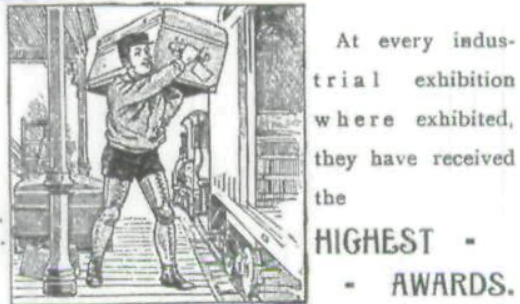

A Treatise containing 430 pages with 260 illustrations sent free, also a formula for taking meas. arements by which limbs can be made and sent to all parts of the world with fit guaranteed.

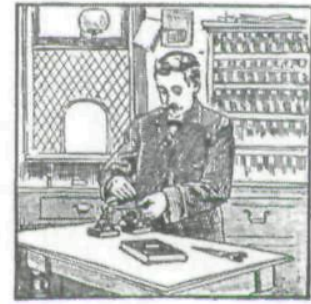

Address

A. A. MARKS, 7or Broadway.

Newe York City

With "artificial limbs," this advertisement implies, disabled trainmen could return to work in various capacities. The advertisement appeared in the Railway Conductor 10 (1893), 28. 
much as he would have earned in eight months. ${ }^{23}$ Realizing that he would never work again, Laughlin told his mother that the railroad company should be made to pay. The family, pressed to financial extremity, decided to sue.

GIVEN THE NUMEROUS OBSTACLES to winning a lawsuit against a railroad company, Laughlin and his family probably carefully considered their options before suing. Indeed, a recent study concludes that railroaders who brought claims fared no better than those who depended on corporate largesse. First, there was the cost of a suit to consider. Companies retained scores of lawyers and could ride out appeals for twenty years. On earnings of forty to fifty dollars per month, or more likely on the family's accumulated savings, most workers simply could not afford to sue. ${ }^{24}$

Once at trial, workers found that companies escaped liability in a number of ways. Lawyers relied on the common-law principle of implied contract, arguing that when trainmen stepped on the job, they accepted all risks associated with their employment, including potential negligence by a fellow employee. ${ }^{25}$ It was especially difficult for trainmen to argue that they were unaware of certain risks, since everything they did was dangerous. Companies also relied on the "fellow servant" rule. Lawyers insisted that the railroad could not be held accountable for the inept behavior of a man's coworkers. Based on the appealing idea that all railroad employees occupied an equivalent status despite differences in rank, salary, and social status, the "fellow servant" rule denied the authority a manager or supervisor exercised over his subordinates. This formidable barrier to financial recovery was at least partly erected by employees themselves. For decades, American skilled workers had declared themselves to be equal to their employers. They based their demands for workplace control on appeals to republican

23. Laughlin earned fifty dollars per month as a baggage master and brakeman. Appellant's Abstract of Record at 2, Muldowney v. Illinois Central Ry. Co.

24. Licht, Working for the Railroad, 199-200.

25. Ibid., 197. 
ideology and their rights as citizen-workers. ${ }^{26}$ Corporations acceded to worker demands for greater control when they gained economic benefits from doing so, as in the case of safety and liability; such a tacit agreement allowed them to throw all responsibility for injuries back on the workers themselves. ${ }^{27}$ Railroads could thus argue, if the occasion called for it, that their employees were competent, reliable workers who should have been capable of evaluating and avoiding risk. The intelligent man, the argument went, refused foolish orders. Courts supported the railroads in this view.

Trainmen recognized, however, that the rapid growth of railroad corporations during the Gilded Age severely limited one's intimate knowledge of a fellow employee's abilities. One switchman remarked, "It is utterly absurd to impute to a brakeman on a train knowledge of the capacity or fitness of a train dispatcher, and to imply that on entering service he is chargeable with knowledge of such fitness or qualifications, when the probabilities are that the train dispatcher is not even known to him personally or by reputation." ${ }^{28}$ Even though the "fellowservant" rule originated when home-based production was the norm and close personal relationships did govern relations between servants, Gilded Age courts still considered everyone except the company president "fellow employees."

The contested definition of "fellow employee" became even more significant when railroads prohibited common, yet dangerous, practices. For example, company rules forbade brakemen from coupling moving cars, even though yardmasters condoned, even mandated, the practice. Thus, railroadersinjured while working as they had been commanded to do-

26. See David Montgomery, Citizen Worker: The Experience of Workers in the United States with Democracy and the Free Market during the Nineteenth Century (Cambridge, 1993), 13-51; Bruce Laurie, Artisans into Workers: Labor in Nineteenth-Century America (New York, 1989), 63-73; Sean Wilentz, Chants Democratic: New York City and the Rise of the American Working Class, 1788-1850 (New York, 1984), 61-103; Christopher L. Tomlins, Law, Labor, and Ideology in the Early American Republic (Cambridge, 1993).

27. See Witt, "The Transformation of Work."

28. Locomotive Firemen's Magazine 14 (1890), 993-94. 
might find that they had broken a little-regarded company rule and so would not be compensated. Rulebooks were also useful for proving contributory negligence. Railroad lawyers picked through such publications to point out all the employee's errors. Courts commonly agreed that it was against company rules to get injured, so injured men had obviously broken a rule.

Iowa railroaders enjoyed one of the most advantageous legal settings in the nation, for in 1862 Iowa's legislature had overturned the strict interpretation of the "fellow-servant" rule. Nonetheless, Iowa's trainmen still found it difficult to win liability suits against the railroads. To succeed, a plaintiff had to prove that his accident resulted from a railroad's failure to practice ordinary care in maintaining a safe workplace. Lawyers often persuaded courts that a business as large as a railroad could not take responsibility for every mismatched coupler, missing grab-iron, or faulty ash pan. Instead, they suggested that a competent, observant employee knew of these ordinary occupational hazards and could avoid them. ${ }^{30}$

Finally, companies that felt crossed by "ungrateful" employees frequently resorted to some bold ploys to escape charges of negligence. When brakeman Nelson Baldwin had his arm crushed after only three days of work, the Chicago, Rock Island and Pacific argued that he was not actually an employee at all! Although the district court quickly halted that line of argument, the railroad later successfully appealed Baldwin's award on those very grounds. ${ }^{31}$ In other cases, companies de-

29. Licht, Working for the Railroad, 199; Emlin McClain, Statutes of Iowa Relating to Railways, and Notes of Decisions Thereunder (Des Moines, 1891), 81.

30. An employee's knowledge diminished a company's liability. When a water spout knocked brakeman Sydney S. Macey to his death (see n. 43 below), the Dubuque and Sioux City Railroad Company successfully filed a motion for a new trial by arguing, "The law is well settled that where an employee engages or continues to work with or in the vicinity of dangerous machinery or structures, with a knowledge or means of knowledge of their unsafe and dangerous condition, he thereby voluntarily incurs the risks incident to his employment with the machinery or structures in such dangerous condition." Appellant's Brief at [19], Greenleaf, v. Dubuque \& Sioux City Railroad Company, 33 Iowa 52 (1871).

31. Appellant's Abstract of Record at 17, Baldwin v. C., R. I. \& P. R. Co., 50 Iowa 680 (1879). 
nied that the broken men appearing before the court had even sustained a disabling injury.

When Edward Laughlin sued the IC, the line battled back with all the legal weapons in its arsenal. Unfortunately for Laughlin, he did not live to defend himself against the countercharges of contributory negligence and incompetence. After eight months of agony, he died. His mother, Anne Muldowney, carried on the suit. The IC's defense team hired three doctors to testify that the dead man's condition had never been life threatening. They argued that Laughlin had caused his own death by attempting to recover too quickly. As one doctor stated, "His condition appeared very flattering and deceived him. ${ }^{\prime \prime 3}$ The district court jury was sympathetic to the bereaved -as they usually were in such cases — and awarded Laughlin's estate ten thousand dollars. The IC immediately appealed to the Iowa Supreme Court, arguing that their counterclaim of contributory negligence had been ignored. Laughlin's family had lost a son; now they stood to lose the liability suit as well.

LEGAL OBSTACLES were not the only barriers disabled trainmen faced in pursuing liability lawsuits. Such lawsuits also pitted injured trainmen against their able-bodied peers in a battle to determine who might claim to be a competent railroader, a reliable comrade, and a true man. Trainmen in Iowa, like men across the nation, tried to convince themselves that their experience would enable them to avoid debilitating, even lethal, accidents. They believed that they possessed skills that their injured comrades could not match and had nerve that deserted men of weak character. Railroading work culture celebrated men who confronted risks coolly, skillfully, and bravely. Men killed in the line of duty were heroes; men who sustained injury but later returned to work were veterans. Disabled workers, dependent on family care and unable to earn a living, how-

32. For example, when John Boyle's ankle got caught between the drawbars of two construction cars and prevented him from working for a year, the Chicago, Rock Island \& Pacific Railroad Company argued that his ankle "had received nothing more than slight bruises." Appellant's Abstract of Record at 4, Boyle v. C., R. I. \& P. R. Co., 56 Iowa 765 (1881).

33. Appellant's Abstract of Record at 26, Muldowney v. Illinois Central Ry. Co. 
ever, often found themselves ostracized from and criticized by their former coworkers. Edward Laughlin's mother, Anne Muldowney, for example, found that her son's fellow trainmen refused to testify on his behalf. Coworkers often interpreted the willingness to sue as prima facie evidence of a man's failure to take responsibility for his own behavior; in seeking to blame another party for his injury, the disabled man admitted that he did not and could not exercise perfect control over his body, his laboring environment, or his economic destiny. At a time when men celebrated bodily self-control and economic independence as critical aspects of working-class manhood, such an admission left the physically disabled worker vulnerable to suspicions of moral weakness.

Employers used their formidable powers of coercion to procure favorable defense testimony in liability suits, yet workers themselves set the agenda for the type of testimony they delivered. Defense depositions reveal that trainmen embedded a discussion of character issues in their testimony on workplace competence. By joining their employers in making occupational disability a moral issue, able-bodied railroaders deluded themselves about their chances of injury and denied the worth and manliness of the injured.

Trainmen's attitudes toward risk, competence, and disability help to explain their testimony and their changing responses to the safety problem. It is important to remember that in the $1870 \mathrm{~s}$ and 1880s most railroaders did not agitate for safety equipment despite the rising casualty rates and the availability of such equipment to their employers. Instead, they relied on their ability to work safely in unsafe conditions. In part, the hiring climate of the time allowed them to maintain a degree of nonchalance. Even if they happened to be modestly injured on the job, trainmen with a slight visible disability (such as a missing finger) might return to work. Throughout this period, railroaders and employers alike viewed a partial disability as a sign of experience. A brakeman's first crushed finger, for example, served as his "red badge of courage" and helped mark his transition from greenhorn to experienced railroader. A man such as "Bellaire the One-Fingered Fireman" continued to work despite horrific injuries, admired by trainmen and managers 


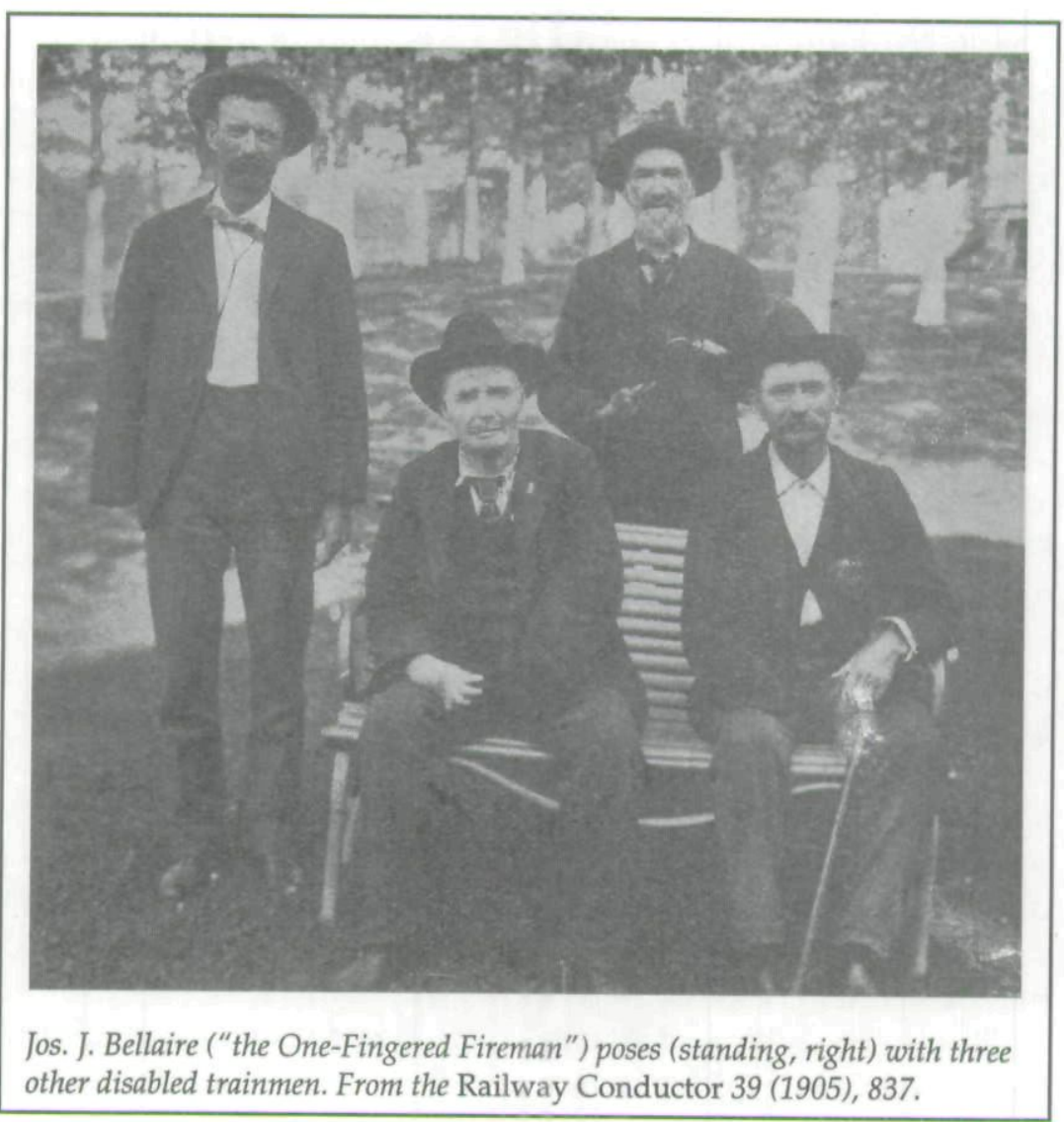

alike. Such a worker had met adversity with manly character and had survived. ${ }^{34}$

Moreover, veteran railroaders viewed fearlessness and risktaking as a sure indication of professionalism. When asked to explain how railroaders controlled their fear, a veteran yardmaster admitted, "Every man who starts in railroading has a fear at the beginning. Sometimes it lasts a few weeks. Sometimes he is always afraid, no matter how many years he is on the road. Such a man will never become a practical railroader, though, even if he has forty years' experience." Crystal Eastman concluded, after a careful assessment of railroaders' attitudes

34. Locomotive Firemen's Magazine 14 (1890), 129; Ducker, Men of the Steel Rails, 55-56. 
toward risk, "Extreme caution is as unprofessional among the men in dangerous trades as fear would be in a soldier. ${ }^{\prime \prime 35}$

Trainmen's memoirs reveal that experienced workers dealt with danger through recognition and confrontation rather than through the avoidance of risk. O. H. Kirkpatrick explained, "The very nature of the trainman's work was so hazardous that it was only those who were disposed to take risks who got very far in their career." He supported his claim by celebrating Shorty, a brakeman and inveterate risk-taker. Shorty took risks "because he could no more control this desire than a sot can control the desire for liquor." Kirkpatrick portrayed Shorty as a genius brakeman, his risk-taking a sign of skill. "I saw him perform hundreds of feats that required perfect timing, alerted reflexes, and the speed of lightning - where the slightest error in any particular would have ended in tragic death." Shorty's fearlessness and quick reflexes led not to the grave, however, but to promotion and a long career as a conductor. ${ }^{36}$

For some railroaders, grappling with danger was the central appeal of the work. Locomotive engineer Henry Clay French supported this most extreme view when he explained, "The danger incident to the engineer's job was the only real incentive to remain at it. ${ }^{\prime \prime 37} \mathrm{~J}$. Harvey Reed glamorized his accidents and near misses, cataloging his disasters in loving detail. For Reed, his frequent accidents merely accentuated his manliness. He explained that railroading was "a life that brave men love, and one that cowards cannot follow. ${ }^{\prime \prime 8}$

In such a work climate, where many railroaders equated the mastery of fear with manliness, and risks successfully flaunted with skill, veterans reserved special scorn for workers who asked

35. Eastman, Work Accidents and the Law, 93-94.

36. Kirkpatrick, Working on the Railroad, 116, 63, 65, 67. Kirkpatrick's comments are based on his observations as a railroader around the turn of the century.

37. Later, when working along the Union Pacific's route that followed the Columbia River, French commented, "Burning bridges in the summer months, falling rock during the winter and spring, gave this work an extra tang of danger that made it interesting." Chauncey Del French, Railroadman (New York, 1938), 116, 137.

38. J. Harvey Reed, Forty Years a Locomotive Engineer: Thrilling Tales of the Rail (Prescott, WA, 1912), 11. 


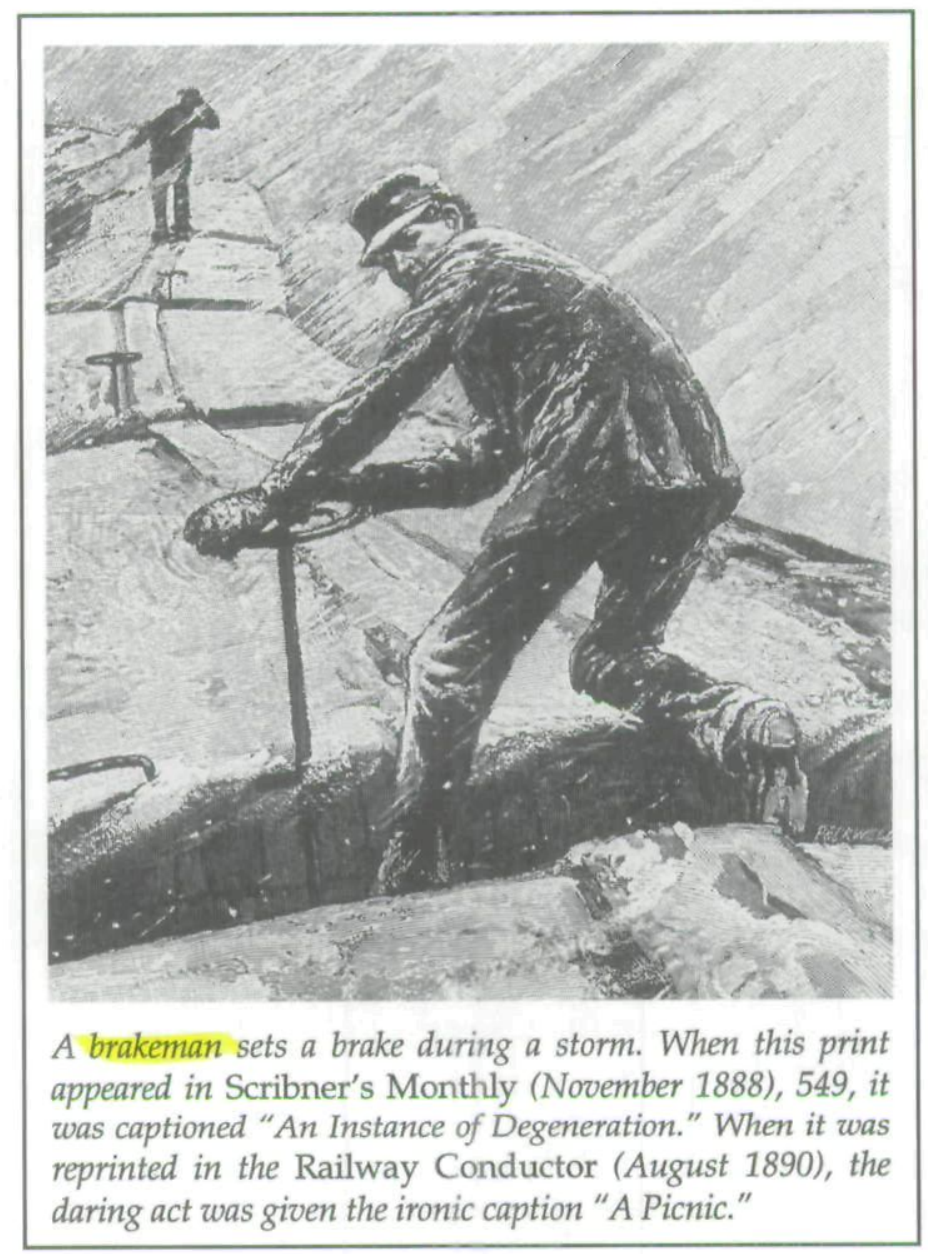

for safety appliances. Many railroaders believed that insisting $44-45$ on such equipment was a way of covering for one's lack of bravery, manliness, and skills. When switchman Frank Pieart, for example, requested that running boards be installed on a yard engine at Atlantic, Iowa, the yardmaster "rather laughed, and said that in other yards they didn't have running boards on engines." Later that day, however, the lack of running boards caused Pieart to be mortally wounded. ${ }^{39}$

39. Appellant's Abstract of Record at 8, Pieart v. Chicago, Rock Island \& Pacific Railway Company, 82 Iowa 148 (1891). 
Railroading work culture also connected risk taking to manliness through a defense of economic autonomy. Some trainmen prized the risky work environment as a means of preserving their own job security. Veteran workers feared that safety devices, such as automatic couplers, would simplify their work and make it easier for replacements to take their jobs during strikes. ${ }^{40}$ The new automatic couplers also eliminated some common tactics used to disrupt the workplace during a strike. Previously, strikers could cripple a yard by stealing all the coupling pins used to link cars together. Strikers could also intimidate scabs by threatening to beat them with the long oaken clubs brakemen carried to drive coupling pins into place. Because the new devices did not use pins, automatic couplers removed railroaders' most immediate sources of redress. ${ }^{41}$

Liability suits that pitted full-time trainmen against parttimers also revealed how veterans used common ideas about risk and competence to besmirch the manly judgment of their injured "temporary" peers. Andrew Reed, for example, worked mostly as a molder in Davenport, Des Moines, Pella, Oskaloosa, and Knoxville. When he could not find molding work, however, he picked up odd jobs in a brickyard or on the rails. In 1879 two cars crushed Reed's hand while he worked as a temporary brakeman. In his subsequent suit against the Chicago, Rock Island, and Pacific Railroad, Reed argued that the fireman, George Dana, had moved the locomotive before Reed had given the signal to proceed; Reed's hand was crushed because he had not expected the train to move. Despite Reed's seven years of intermittent experience, the rest of the crew testified to Reed's ignorance of rail operations. Dana claimed that Reed had indeed given him the signal to come ahead, implying that no one who knew how locomotives reacted after striking a car would have been surprised or injured. When Reed argued that the drawbars he had been coupling were irregular, the hind brakeman, who made the coupling after Reed was hurt, disputed

40. This had actually happened on the New York Central, where, during a strike, rolling stock equipped with automatic couplers were "found to be a great help to the new employees in handling cars." Locomotive Engineers' Monthly Journal 24 (1890), 877-78.

41. Ibid., 878 . 
him. ${ }^{42}$ The rest of the train crew viewed Reed as an interloper, an impression Reed reinforced when he blamed Dana for the accident rather than living up to the railroad code of manliness and taking responsibility for his own safety.

Defense testimonies in Edward Laughlin's lawsuit also exemplify these attitudes toward work, risk, and injury. The IC claimed that Laughlin's own incompetence caused his injury; his fellow workers agreed. Brakeman E. P. Lovejoy testified that he "thought the cars were coming too fast to make the coupling with safety." If Lovejoy had recognized the danger, why hadn't Laughlin? The conductor of the train suggested that experienced railroaders knew that the bumpers might misalign. Finally, the engineer of the train, with eighteen years on the rails, reaffirmed Laughlin's incompetence when he commented, "I have never saw such a coupling attempted since I have been railroading, when the cars were running as fast as those . . . Laughlin attempted to couple." Laughlin's judgment, like his skill, had been wanting. ${ }^{43}$ On appeal, the Iowa Supreme Court reversed the district court ruling in Laughlin's case because the jury had been too willing to overlook Laughlin's supposed contributory negligence.

42. Appellant's Abstract of Record at 3-9, Reed v. C., R. I. \& P. R. Co., 57 Iowa 23 (1881).

43. Appellant's Abstract of Record at 14, 21, and 23, Muldowney v. Illinois Central Ry. Co. This type of testimony was common. For example, when the water tank spout at Ackley - the same station where Laughlin met his fate-knocked brakeman Sidney Macey to his death, workers avowed that Macey's incompetence (rather than the unsafe conditions in which he worked) brought about his downfall. Baggage master and former brakeman Stephen Bonner, bragging about his own skills, explained, "I have done the same thing that Macey was doing when he was killed a hundred times over, but I always got clear to the side of the cars and avoided the spout." Appellant's Brief at [8], Greenleaf v. Dubuque \& Sioux City Railroad Company. Of course, some trainmen may have judged their injured comrades as incompetent for more selfish reasons. The locomotive engineer driving the train on which Nelson Baldwin was working concluded, "He could not have a more favorable opportunity to couple cars than he had at [the time of the accident], and the injury or accident could not have happened to him ... if he had understood his business." The engineer refused to consider that he might have contributed to Baldwin's injury by improper operation of the switching engine. Appellant's Abstract of Record at 19, Baldwin v. C., R. I. \& P. R. Co. 
SOME TRAINMEN grudgingly admitted that there were limits to a man's ability to protect himself. When they attempted to purchase insurance policies as individuals, however, they were refused. One engineer explained, "I did not receive a policy, simply because I was a Locomotive Engineer, which they classed as 'extra hazardous. ${ }^{\prime \prime 44}$ In response to such discrimination, groups of railroaders formed mutual aid societies or fraternal orders. Such organizations, called brotherhoods, provided economic security for members and their dependents when their skills were not enough to compensate for the risks of their profession. ${ }^{45}$ The Brotherhood of Locomotive Engineers (BLE) established the first brotherhood insurance association in 1867. Its fund paid members for the loss of a hand, foot, or limb, or total blindness; survivors received death benefits. The Brotherhood of Locomotive Firemen originated as a benevolent insurance association, although disability insurance constituted a separate policy. The Order of Railroad Conductors established an insurance fund in 1882; the Brotherhood of Railroad Brakemen quickly followed suit in 1884. The Switchmen's Mutual Aid Association of North America established a locally administered guaranty fund for its members in 1886 . Some brotherhood locals also ran their own benevolent funds and helped disabled members by providing food and paying doctor bills. ${ }^{46}$

As time progressed, the brotherhoods expanded their purpose and took on some of the characteristics of unions, including limited efforts to bargain collectively with employers for higher wages and better conditions. Not surprisingly, given the average trainman's attitudes, brotherhoods considered the certification of competence, manliness, and safety as their biggest bargaining tools. The BLE, for example, sought to prevent accidents, certify member competence, and instill manly behavior.

44. J. C. P. to BLE, Chicago, 11 May 1868, Locomotive Engineers' Monthly Journal 2 (1868), 164, quoted in Reed C. Richardson, The Locomotive Engineer, 1863-1963: A Century of Railway Labor Relations and Work Rules (Ann Arbor, MI, 1963), 132. 45. The following railroad brotherhoods were formed in rapid succession: the Brotherhood of Locomotive Engineers (1863); the Order of Railway Conductors (1868); the Brotherhood of Locomotive Firemen (1873); the Brotherhood of Railroad Brakemen (1883); and the Switchmen's Mutual Association (1886).

46. ICC, Report, 1889, 387-90. 
BLE leaders used a variety of journal articles, letters, and poems to promote a model of manly behavior based on the motto of the organization: "Sobriety, Truth, Justice, and Morality." ${ }^{47}$ Railroad companies, the BLE hoped, would recognize the superior character of member engineers and hire them exclusively. All of the brotherhoods promoted safety, manly character, and economic security as part of a single trade identity, although they differed widely in their conceptions of ideal relations between workers and management.

Although only a portion of Iowa's trainmen belonged to the brotherhoods at any given time, these societies influenced the character of labor-management relations in the state. A brief examination of these organizations, focusing on the BLE, suggests the ways the railroad brotherhoods both reflected worker ideologies and crystallized ideas concerning competence, professionalism, and safety into a coherent argument for increased power in labor negotiations.

The BLE, like other brotherhoods, attempted to enforce high standards of behavior to ensure that their members impressed company officers. $^{48}$ From its inception, therefore, the BLE insisted that the true railroad professional was moral, intelligent, competent, and temperate. The membership qualifications for the BLE stressed these attributes: "No man can become a member of the brotherhood unless he is twenty-one years of age, has had one year's experience as a locomotive engineer, is of good moral character and temperate habits, and can read and write. ${ }^{\prime 49}$ Engineers could only be promoted due to "merit and ability,"

47. See, for example Locomotive Engineers' Monthly Journal 4 (1870), 198, 215; ibid. 18 (1884), 338-40; ibid. 20 (1886), 706-8; ibid. 26 (1892), 423-24; and ibid. 33 (1899), 776.

48. Indeed, officers such as Charles Hine of the Burlington commented that "to be respected [the brotherhoods] must purge their ranks of the morally unfit. The union must expel the thief and the ruffian, if justly discharged by the company, before it can hope to be trusted as a judge of capacity." Charles DeLano Hine, Letters from an Old Railway Official to His Son, a Division Superintendent (Chicago, 1904), 166.

49. ICC, Report, 1889, 387. A less noble membership qualification was that of race. In 1867 the BLE officially excluded African Americans from membership in the brotherhood. Philip S. Foner, History of the Labor Movement in the United States, 2 d ed., 10 vols. (New York, 1975), 2:248. 
with the length of service varying "depending to a great extent on the character of the man." BLE leaders took credit for ridding the profession of riff-raff, claiming that "the brotherhood has been instrumental in giving the railway companies a better class of men than they would otherwise have had. . . . Whenever a man is detected dissipating, he is punished and the officers of the road notified of the same." ${ }^{150}$

Throughout the Gilded Age, brotherhoods attempted to increase their bargaining power by convincing the public that only brotherhood members possessed the skills to avoid accidents. During the 1888 Burlington strike, for example, when the $C B \& Q$ replaced striking BLE members with scabs, the strike committee warned passengers about unsafe conditions on "The Great American Scab Route." Their broadside cautioned that "a railroad like the $C B \& Q$ cannot run with threshing machine engineers and vagrants and drunkards in the places of their old reliable engineers and firemen" (see illustration, following page). By accusing scabs of insobriety, inexperience, and incompetence, BLE leaders built upon the widespread belief that steadiness, safety, and competence were solely the province of the true railroader-a status that only brotherhood men could claim.

The BLE and other railroad brotherhoods did more than simply capitalize on preexisting ideologies of railroad manhood. Through their monthly publications, they also hoped to transform their members' habits and shape their tastes. For example, one could easily mistake the early volumes of the BLE's monthly journal for a temperance society publication, even though many members continued to enjoy drinking at the trackside saloon. Brotherhood journals also occasionally downplayed sectarian, partisan, and sectional differences to present a unified organizational front.

50. ICC, Report, 1889, 387.

51. For an examination of the relationship between saloon culture and the working class, see Roy Rosenzweig, Eight Hours for What We Will: Workers and Leisure in an Industrial City, 1870-1920 (Cambridge, 1983), 34-64. Alcohol was a persistent problem on nineteenth-century railroads. Paul V. Black found that between 1877 and 1892, alcohol played a role in over 29 percent of all employee discharges on the CB\&Q. Paul V. Black, "Experiment in Bureaucratic Centralization: Employee Blacklisting on the Burlington Railroad, 1877-1892," Business History Review 51 (1977), 451. 


\section{TAKE THE GREAT AMERICAN
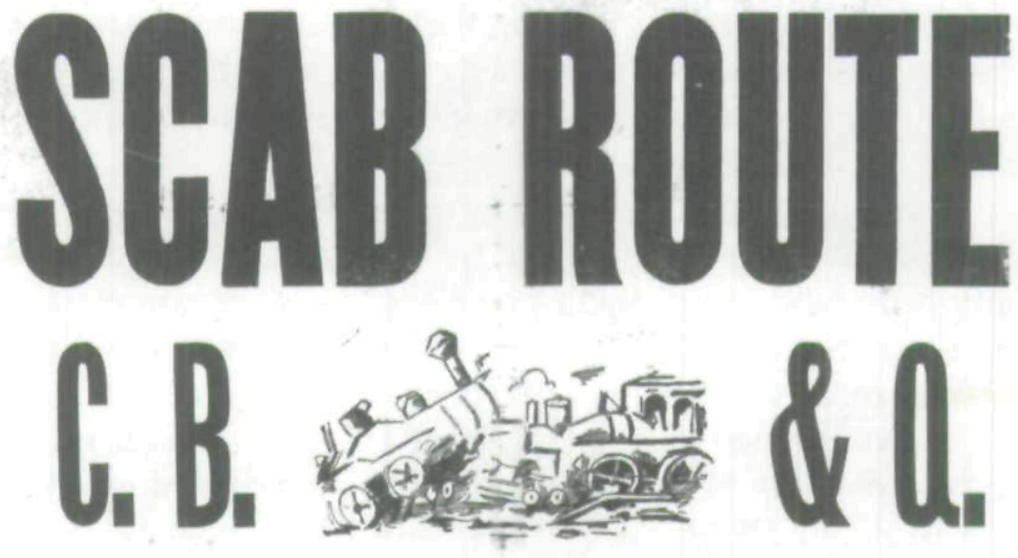
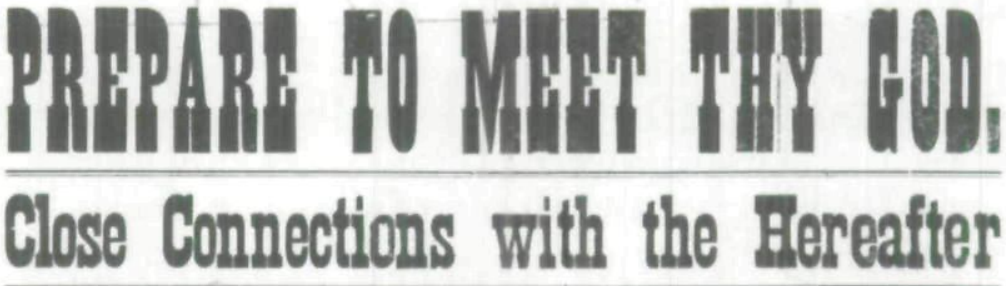

\section{THROUGH TICKETS TO POINTS THE STYX.}

N. B-Death Claims Promptly Settled.

FAMU TWE WHOQRE OEMOCRAT.

PAUL MORTON, G. P. A. M. L. General Prevarioator and Monumental Liar.

The strike is finot off, nor will it be until the C. B. \& 9 . busines public of good judgment will not patronize a mad which recegnises the fact that it must pay as good wages as its is at present a menace to life and property, and a nud which competiton, and then siga a treaty with its old eagiecers and aceks to erush out an onzanization which has done more th firemen, wo had worked, and been so sacerenful in bringing it make traveling a safety than all the companies on this contiup to its former standing and standand of excellence.

The poblic realize the faet that a railroad like the C. B. \& engines, and an organization which practioes industry, sobri:ty Q. cannot be run with threshing machine engineers and vag- truth, justice, and morality.

rants and druakards in the places of their old reliable engineers

and firemen; and the working men and their friends of the!

St. JoskPu, Jusk 8 , 1888

CомMITTE

Strikers' broadside, 1888, courtesy of Chicago Historical Society.

Yet there were some principles upon which all members apparently agreed. For example, brotherhood members harbored harsh attitudes toward the unemployed, whom they 
viewed as probable incompetents as well as potential competitors. An article in the BLE's Monthly Journal criticized unemployed mechanics. "Mechanics out of work are generally men who are not the best in their line. . . . The slovenly, slow, inefficient, negligent and unintelligent workman is the one who always marches first when reduction in force is necessary, and it is he whom we hear most often prating in the grog-shops about the oppression of capital and the tyranny of employers. ${ }^{\prime \prime 2}$

Among the most serious issues confronting the railroad brotherhoods, of course, was how best to address the physical and financial woes of disabled members in a way that upheld their ideals about competence and manliness. BLE members reasoned that their insurance fund, far from rewarding incompetence, allowed men to act heroically. N. W. Holbrook explained that joining the plan was "a duty that we owe the public ... to relieve ourselves of [financial] responsibility, so that in time of danger we can stand manfully to our station, and sacrifice our lives, if necessary, knowing that upwards of seven thousand brothers stand ready to relieve the wants of our families. ${ }^{153}$ Not all members conceded the need for insurance, but those who did subscribe saw it as an aid to manliness rather than as a crutch for the unskilled. Most also drew a sharp distinction between insurance benefits and charity. Insurance policies represented a prudent investment in continued independence should the unthinkable occur; charity was the last recourse of the improvident.

Yet one of the foundational precepts of the brotherhoods was charity. Certain locals prided themselves on extending a helping hand to the families of the killed and injured men who had not joined the insurance program. Men found it far more palatable to aid widows and orphans, however, than they did their own comrades. Some members interpreted the lack of fiscal foresight (failure to provide for contingent emergencies through insuring oneself) as an indication of failed manliness on the part of the uninsured disabled; they demanded to know why they should behave charitably towards men who had shirked one of the fundamental duties of a husband and father. ${ }^{54}$

52. Locomotive Engineers' Monthly Journal 24 (1890), 591.

53. Ibid. 4 (1870), 83.

54. See, for example, ibid. 34 (1900), 294. 
Moreover, brotherhood members believed that the power they exerted in the labor-capital relationship depended on their ability to convince railroad companies that members were competent, safe men. If their self-conceptions were correct, brotherhood members were the prize specimens of railroad manhood and should have been able to negotiate risks successfully. Yet some clearly had not triumphed over danger. How could the brotherhoods continue to claim the competence of its membership under such circumstances? Most chose to blame the individual worker rather than forfeit the politically powerful connected claims of competence, manliness, and safety. Sharing the sentiments of most trainmen, members often judged their disabled comrades as lacking in virtue as well as skill. Those who would compound their errors by asking for charity were double failures: responsible for their injuries due to incompetence, inexperience, or intemperance and responsible for their poverty due to lack of foresight. Members were loath to provide charity to "unworthy" characters who would surrender their dignity and independence rather than insure themselves. Widespread charitable initiatives, like any systematic demands for safety reform, foundered on the shoals of contempt for the disabled. Although fraternally bound to each other, brotherhood men continued to shoulder the burdens of risk alone.

BY THE FINAL DECADE of the nineteenth century, however, trainmen faced changing conditions in the workplace that forced them to reexamine their attitudes towards masculinity, disability, and safety. Previous understandings between workers and employers broke down as corporations rationalized their bureaucracies, pursued greater efficiencies, and established scientific management policies. In Iowa and nationally, hard times and higher injury rates compelled railroad officers and trainmen to confront the sobering realities of occupational disability head-on.

Worker anxieties mounted as hiring opportunities diminished. By the end of the $1880 \mathrm{~s}$, most railroads refused to hire even slightly disabled trainmen. Companies manifested an increased mania for efficiency and feared that disabled trainmen would work too slowly and would be more susceptible to injury. 


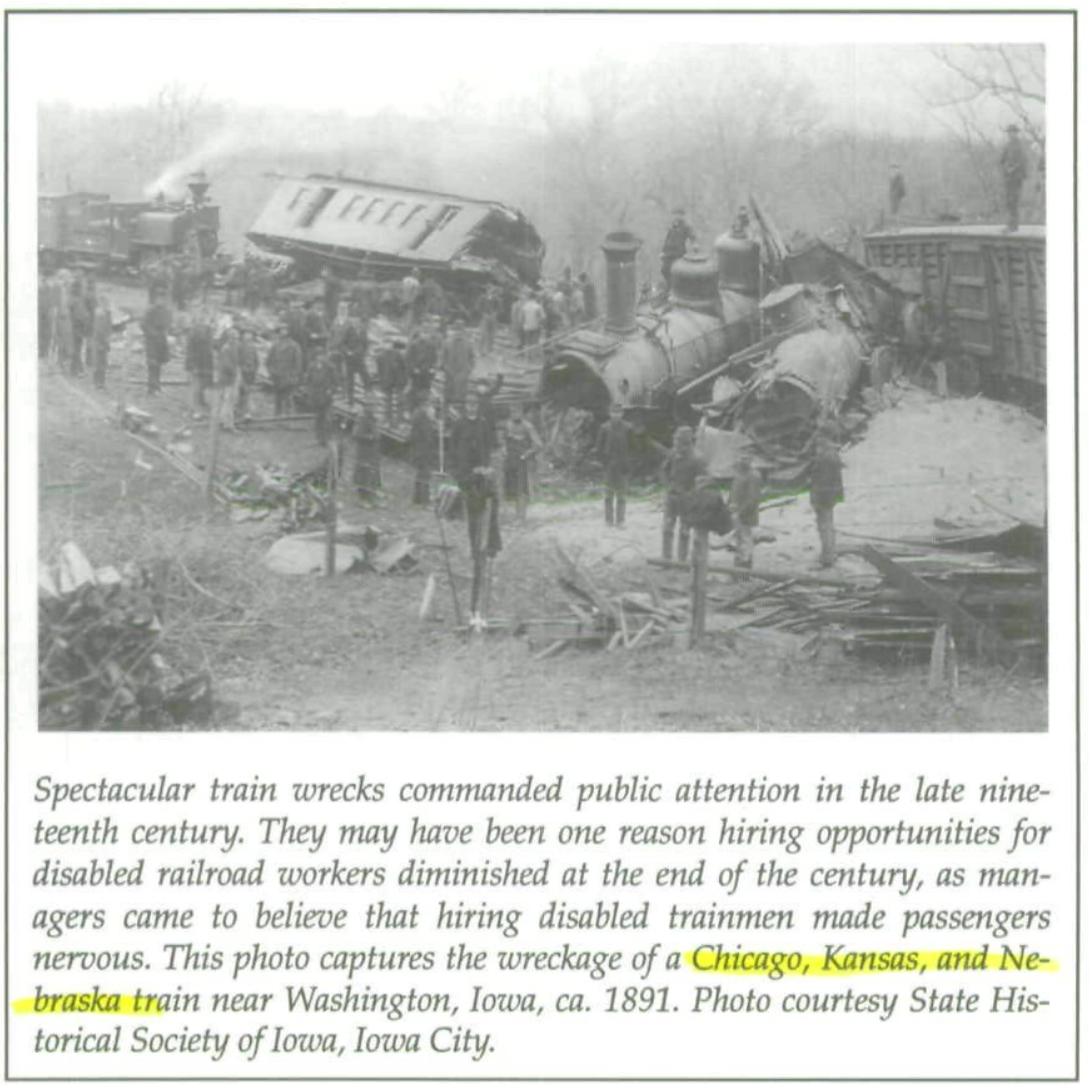

Managers also believed that employing men with disabilities made passengers nervous. The image of railroader as risk-taker was firmly fixed in the public mind, and some riders perceived that disabled men lacked either nerve or prudence. Finally, L. L. Losey, chief claim agent of the IC, explained that by rejecting disabled men, lines protected themselves "against fraudulent claims for pre-existing injuries $v$ hich otherwise might be charged to an accident while in service. ${ }^{\prime \prime 55}$

The Chicago and North Western typified the trend to discriminate against men with disabilities when it refused to give

55. L. L. Losey, "The Relntions between the Surgical and Claims Departments of Railroads," pamphle: reprinted from the Railway Surgical Journal (March 1908), 3, Newspaper Clippings, 1899-1915, IC 2.9 v. 18, Illinois Central Archives, Newberry Library; Ducker, Men of the Steel Rails, 121-22. 
E. B. Jessup the job he had been promised. The officer in charge of Jessup's case explained that he was "determined not to put any more cripples on the engines. "The case report noted that the officer "says he has one cripple in here and he don't want any more. He has trouble with cripples on an engine." Jessup, like many disabled Iowa trainmen, was then forced into a less lucrative job. Andrew Reed, who found it impossible to return to his primary occupation as a molder after his coupling accident, ultimately found that he was incapable of earning a living at any type of manual labor. Nelson Baldwin tried to become a cigarmaker. His crushed arm, however, prevented him from keeping pace, and he soon found himself waiting tables. After struggling with jobs that demanded arm strength and dexterity, Baldwin decided his useful work-life was over. Each man, in an earlier time, might have gotten a less taxing job on the railroad. Conditions had changed, however. Each man decided to sue rather than to succumb without a fight to the downward spiral of poverty. ${ }^{56}$

In an effort to reduce expenditures and evade liability in the face of such lawsuits, railroad companies began to set up relief departments, surgical departments, and claim departments in the $1880 \mathrm{~s} .{ }^{57}$ Despite the appearance of corporate benevolence, employees contributed most of the funds for these endeavors. Moreover, workers were required to join the "voluntary" fund or be fired. Workers quickly came to resent the relief funds. Mandatory enrollment denied trainmen the opportunity to make independent choices about how best to protect themselves and their families from risk. Some men rejected the idea that they needed insurance at all. Moreover, organized workers rightly suspected that relief funds had been designed as a cor-

56. Appellant's Abstract of Record at 3, Jessup v. Chicago \& Northwestern Railway Company; Appellant's Abstract of Record at 3, Reed v. C., R. I. \& P. R. Co.; Appellant's Abstract of Record at 12-13, Baldwin v. C., R. I. \& P. R. Co.

57. Aside from the Illinois Central's short-lived "IC Relief Club," the first companies to set up voluntary relief departments were the Baltimore and Ohio Railroad in 1880 and the Pennsylvania Railroad in 1886. Hazlett and Hummel, Industrial Medicine, 38-39; Licht, Working for the Railroad, 210. The CB\&Q set up its relief fund in 1889. See J. C. Welling to Stuyvesant Fish, 6 February 1896, Bundle of Letters Concerning Prospective Relief Department, 1896, IC 3.4, box 6, Illinois Central Archives. 
porate ploy to diminish the lure of the railroad brotherhoods, which offered insurance as a membership benefit. Edward O'Shea, an officer of the Brotherhood of Railroad Brakemen, bitterly summarized the prevailing brotherhood view.

Some of the principal lines have lately organized so-called "relief associations" for the ostensible purpose of "caring for our dear employes," but the real purpose is to undermine and ultimately destroy the brotherhood and place the men entirely at the mercy of the corporations. The brakeman does not receive wages commensurate with the work he performs or the dangers he is compelled to undergo; hence, he is unable to keep up his membership in more than one organization. ... A protest will result in a discharge, and a discharge forfeits all moneys paid into the fund. The relief fund is a delusion and a snare, and many of the brakemen know it from bitter experience. ${ }^{58}$

Finally, railroaders soon learned that they were even less likely to secure compensation through the relief funds than through litigation. Railroad surgeons, hired by the company, played a pivotal role in railroad companies' efforts to avoid liability. They had sole discretion to decide whether a company would compensate an injured employee. The railroad surgeon's first duty was to determine whether injured employees were entitled to relief funds. Caring for injured men was of secondary importance. $C B \& Q$ surgeons were instructed to interrogate injured employees as soon as they arrived for care, because "a person will then usually give a more truthful and explicit statement than [after meeting with] sympathizing or designing friends. ${ }^{\prime \prime 59}$ Moreover, men who applied for relief funds first had to release the company from any legal liability, foreclosing the possibility of disputing the surgeon's decision before a court of law. Workers thus legitimately suspected that escaping liability had been the primary reason that companies established voluntary relief departments. ${ }^{60}$

In 1883 C. E. Perkins, vice president of the CB\&Q, wrote a long memorandum concerning the $C B \& Q$ surgical department.

58. ICC, Report, 1889, 388-89.

59. Losey, "Relations between Surgical and Claims Departments," 3.

60. See Eastman, Work Accidents and the Law, 195-206. 
Humanitarian concerns were far down his list of reasons for establishing such a department. Perkins's primary concern was to ensure that the line had "precise knowledge as to the extent and character of personal injuries." Perkins believed that the company could limit liability claims by deciding what constituted an injury. He insisted that "no surgeon except those appointed by the Company ... shall be called by any employee to attend cases of personal injury." ${ }^{\prime 61}$ Employees who wanted the company to pay for any of their medical care were thus denied the right to a second opinion. Without contrary testimony from another physician outside of the railroad's employ, liability cases could not succeed.

When company surgeons did place worker welfare before financial considerations, companies quickly disavowed their decisions. In 1887 the Iowa Supreme Court supported the company view, ruling that railway surgeons had no authority to bind a company to pay for an injured employee's care, even if the care was recommended by the company's surgeon. ${ }^{62}$ In Iowa, then, railway surgeons were hired primarily to protect company finances, and the practice had the backing of Iowa law.

Railroads also explored the possibilities of establishing company hospitals to limit employee injury claims and inspire employee loyalty. In 1880 C. E. Perkins wrote to A. N. Towne, general superintendent of the Central Pacific, to inquire about that line's hospital system. Towne assured Perkins that company hospitals were an affordable way to reduce liability and instill corporate loyalty. Apparently, however, many trainmen objected to the mandatory fifty-cent monthly fee deducted from workers' salaries for the privilege of receiving emergency medical care, for Towne admitted that "inconsiderate, bad men" sometimes caused problems for the company by demanding their full wage packet. He assured Perkins that such troublemakers "were not given a second opportunity [to object to the wage deduction], being summarily dismissed." Railroad offi-

61. C. E. Perkins, "Memorandum: Surgical Department," 11 December 1883, C. E. Perkins In-Letters, July-December 1883, CBQ 3 P6.36, CB \&Q Archives.

62. Bushnell v. Chicago \& Northwestern Ry. Co., 69 Iowa 620 (1886); Iowa Board of Railroad Commissioners, Tenth Annual Report ... for the Year Ending June 30, 1887 (Des Moines, 1888), 819 (hereafter cited as IBRC, Report, [year]). 
cials quickly perceived the value of hospitals that were financed through mandatory employee contributions yet completely controlled by company officers and railway surgeons. ${ }^{63}$

The IC was slow to open hospitals, hire surgeons, or develop insurance funds. ${ }^{64}$ Instead, it chose to reduce costs by centralizing accident claims processing. Gratuity applications were handled on a case-by-case basis in the 1860s and 1870s. By the mid-1880s, the sheer volume of occupational disability cases and the potential costs of such cases forced companies to reconsider the personal approach to accident settlements. Many rail lines set up personal injury claim departments within their legal departments. Lawyers and claim agents negotiated out-of-court settlements, retained and supervised company lawyers, kept track of expenditures, and policed fraudulent claims. ${ }^{65}$

The increased rationalization undoubtedly saved companies money; it also marked a significant departure from previous

63. A. N. Towne to C. E. Perkins, 30 January 1880, Papers Concerning Employees, 1877-1898, CBQ 331870 3.6, folder 1, CB\&Q Archives. Although the $C B \& Q$ discussed opening hospitals, it did not set one up in Iowa during this period. Aside from the Atchison, Topeka and Sante Fe hospital at Fort Madison, railroad workers did not have access to company-sponsored hospitals in Iowa during the late nineteenth and early twentieth centuries. U.S. Department of Commerce and Labor, Bureau of the Census, Benevolent Institutions, 1904 (Washington, DC, 1905), 148-49; ibid., 1910 (Washington, DC, 1913), 288-89.

64. When the IC acquired the Chesapeake, Ohio and Southwestern in 1896, it inherited hospital facilities at Paducah, Kentucky. As late as 1910, however, that was the only hospital it operated. John F. Stover, History of the Illinois Central Railroad (New York, 1975), 230; U.S. Department of Commerce and Labor, Bureau of the Census, Benevolent Institutions, 1910 (Washington, DC, 1913), 288-89. The IC made the Railway Officials and Employees' Accident Association of Indianapolis the official private insurer of the IC in 1898. For the protracted discussions leading to the establishment of the corporate insurance plan, see J. C. Welling to Stuyvesant Fish, 6 February 1896; Lightner, Labor on the Illinois Central Railroad, 377. On the IC's insufficient attempts to establish a relief department during the last three decades of the nineteenth century, see also ibid., 269-74.

65. See Report of Cases Pending in Illinois and Iowa, in Minutes of Meeting of Board of Directors, 1887, microfilm reel 9.351, IC Archives; Annual Report of General Solicitor of Illinois Central Railroad as of December 1, 1888, in Minutes of Meeting of Board of Directors, 1888-1889, microfilm reel 9.352, ibid.; and James Kells, "Exposes Fake Injury Claims," Newspaper Clippings, 18991915 , IC 2.9 v. 18 , ibid. 
underlying ideas about disability. Personal involvement with or knowledge of the circumstances of one's employees, to the extent that company officers had been involved in diagnosing the moral dimension of worker injuries, was increasingly replaced by purely financial considerations. Agents (like other insurers) began to behave as though a lost arm, like a broken lever, had a consistent and knowable "replacement" price. W. R. Head, the IC's "personal injury agent," aptly reflected the increasingly callous attitude of professional claims agents when he downplayed both the sufferings of the injured and the seriousness of corporate negligence; in his view, "all great undertakings [were] attended with their peculiar accidents."

What effect did the existence of claims departments have on the settlement of disability cases in Iowa? In the personal injury and fatality cases disposed of by the IC during the early 1890s, the corporation successfully used its agents to induce employees or their administrators to settle for far less than their initial claims. In 1889, at Webster County District Court in Fort Dodge, Iowa, Peter Roy sued the IC for twelve thousand dollars for the death of brakeman Albinus Roy. A year later, Peter Roy settled for only five hundred dollars, or 4.2 percent of the original damages sought. In 1891 Mary Stewart settled for eight hundred dollars, or 5.3 percent of her original fifteen-thousand-dollar suit; her husband, brakeman A. J. Stewart, had died in a coupling accident two years earlier. Nelly Lumley tried to recover $\$ 4,980$ for the death of her husband, brakeman Edward R. Lumley, but finally settled for \$305. Between 1890 and 1893, the IC settled nine cases; half of the litigants received less than 6 percent of their original claims. ${ }^{67}$ Many widows were elated to win in district court, only to learn from claims agents that the appeals process could drag on for years. Agents were quick to remind the bereaved that even if administrators won in the state supreme court, their lawyers might wind up with more than half of any eventual award. Exhausted economically and emotionally, a fair

66. W. R. Head to James Fentress, 12 November 1892, IC 3.4, box 5, IC Archives.

67. Minutes of Meeting of Board of Directors, 1890, microfilm reel 9.354, IC Archives; Reports of the General Solicitor, 30 June 1891 and 19 November 1892, in Injury Reports, 1891 and 1893, IC 3.4, box 5, ibid.. 
number of women decided (at the urging of company agents) to take what they could get in an out-of-court settlement.

Injured employees on the IC received somewhat larger settlements than those who died, perhaps because injured victims were more likely to pursue litigation to the bitter end than the families of fatalities. F. H. Knott, a fireman on the IC-controlled Cherokee and Dakota Railroad Company, was injured when he fell into a coal tender. In October 1889 he sued the railroad for twenty-five thousand dollars. When the Lyons County District Court awarded him nine thousand dollars, the IC appealed. After three years of legal wrangling, Knott triumphed in the state supreme court, receiving 40 percent of his initial request for damages. ${ }^{69}$

Thus, by the early 1890 s, changing conditions had rendered workers increasingly vulnerable. When railroad companies refused to hire even slightly impaired men, trainmen began to fear that the smallest injury might spell the end of their career. This was only one aspect, however, of a contradictory course that challenged previous shared understandings about the worker as an agent of his own economic and physical destiny. Lines began to mount systematic attacks on worker control, removing critical decisions concerning health and safety from the realm of the trainman's individual judgment. Companies further signaled their retreat from the older understandings of disability when they rationalized systems of corporate relief for the injured; companies increasingly preferred to think of injured workers not as individuals but as a predictable cost of business. Broken trainmen, like broken machines, would occasionally need new parts for which a railroad might budget. It was cheaper by far to invest in new workers than in safety equipment, and rail lines proceeded accordingly. At the same time, however, corporations also attempted to evade or

68. See correspondence regarding Mrs. Hinzeman, Mrs. Carroll, Mrs. Jacobson, and Mrs. Chase, Gratuities, L. O. Goddard In-Letters, Miscellaneous, 18821896, CBQ 3 G5.3, CB \&Q Archives.

69. Minutes of Meeting of Board of Directors, 1890, microfilm reel 9.354, IC Archives; Reports of the General Solicitor, 30 June 1891 and 19 November 1892, in Injury Reports, 1891 and 1893, IC 3.4, box 5, ibid.; Minutes of Meeting of Board of Directors, 1889-1890, microfilm reel 9.353, ibid. 
diminish their liability by claiming that trainmen were still responsible for the consequences of poor individual decisions. Finally, companies still hoped to preserve their individual relations with workers when it came to matters of hiring, firing, and negotiating - they disliked railroad brotherhoods and attempted to erode worker solidarity by manipulating companysponsored insurance plans. Trainmen quickly recognized the conundrum. On one hand, corporations denied their individuality when it served company interests; on the other, companies attempted to take advantage of their individual weaknesses. Railroaders interpreted the contradictory practiceswhich denied them control, increased their risk, and provided little in return-as an assault on their prerogatives as workers and as men. As they reconsidered their relationship with capital, trainmen also would be forced to rethink their position on disability.

RAILROAD WORKERS and their brotherhoods would not be alone in reconsidering safety conditions on Iowa's railroads, however. Iowa's legislature began to take notice of railroad injuries and deaths in 1878, when it created the Board of Railroad Commissioners. The commission, consisting of three members appointed by the governor, primarily concerned itself with straightening out squabbles over shipping rates, but it also compiled yearly reports concerning railroad business in the state. Each year, that report amassed state accident statistics. As the casualties mounted throughout the 1880s and 1890s, safety advocates began to plead for legislative action.

Iowa's railroad injury and death statistics provide a statewide snapshot of a national problem. In 1878, the first year of data collection, 1 percent of Iowa's 13,518 railroad workers sustained an injury. ${ }^{70}$ For the next twenty-five years, yearly injury totals ranged from 0.7 to 2.9 percent. The commissioners were especially concerned with coupling accidents, which caused more than half of all reported injuries during the late 1870 s and early 1880 s. In their 1882 report, the commissioners commented,

70. These, as well as the following numbers, are derived from the annual reports of the Iowa Board of Railroad Commissioners, 1878-1905. 


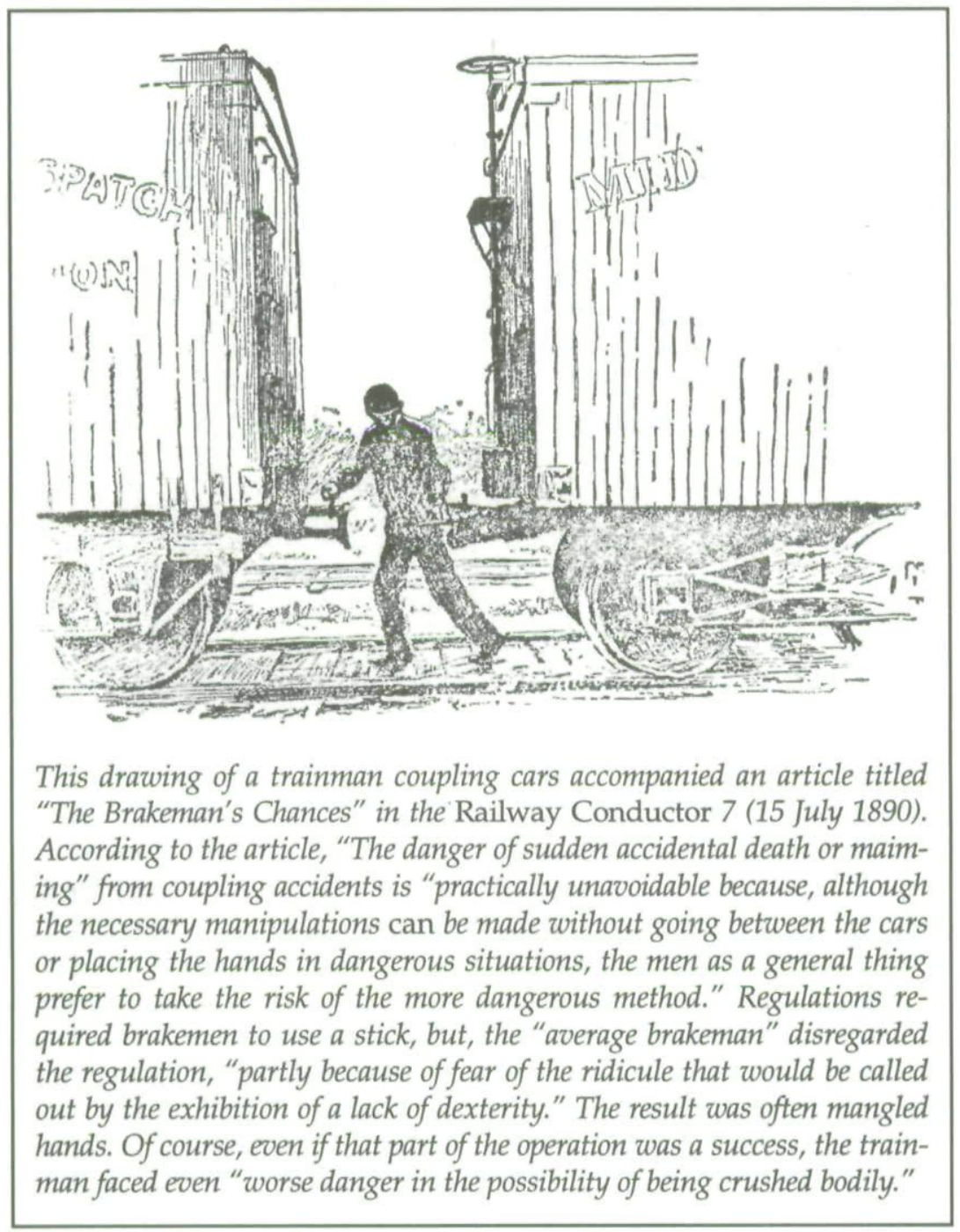

"There is evidently something wrong in the entire arrangement of coupling cars, for in no legitimate business should there be such a liability to injury and death. We are not able to suggest a remedy, but believe that something might be provided that would do away with much of this." ${ }^{\prime 11}$ Two years later, the com-

71. IBRC, Report, 1882 (Des Moines, 1882), 21. 
missioners were prepared to offer a remedy. They strongly backed the actions of the Massachusetts General Assembly, which had just passed an act that made railroad companies operating in Massachusetts place safety or automatic couplers on new and newly repaired rolling stock. Iowa's railroad commissioners remarked, "We look for the action of Massachusetts to be followed everywhere, either by the voluntary act of the railway companies or by legislative enactment, until the appalling list of killed and injured from this cause shall belong to the past." ${ }^{\prime 2}$ The commission's collective indignation and enthusiasm for state regulation of private industry did not last. In subsequent 60. years, the commission as a whole would be unwilling to recommend mandatory safety regulations. ${ }^{73}$

Instead of demanding legislation to force railroad companies to install life-saving equipment, the commissioners tried to mitigate public concern by stating that Iowa was doing a better job of preventing injuries than most states. One annual report claimed-with absolutely no statistical evidence to support the contention-that when comparing the frequency of accidents with railroad mileage, "Iowa was below the general average. ${ }^{\prime 74}$ A closer examination of the commission's numbers, however, indicates that they vastly underestimated the number of injuries and deaths among Iowa's railroaders. By including employees who were seldom exposed to danger, such as general officers, general office clerks, and station agents, the commission reduced the perceived effects of injury by inflating the reported number of employees they considered at risk. When at-risk employees such as enginemen, firemen, conductors, brakemen, trackmen, and switchmen are considered separately, railroading accident statistics become even more alarming. ${ }^{75}$

72. IBRC, Report, 1884 (Des Moines, 1885), 41.

73. In 1887, when Lorenzo S. Coffin produced a report in favor of mandatory legislation, the rest of the members "thought best that he alone should be responsible for it." IBRC, Report, 1887 (Des Moines, 1888), 59.

74. Ibid., 39.

75. Although the commission did not record specific categories of railroad employees before the mid-1890s, it is still possible to approximate the percentage of trainmen in Iowa. From 1895 to 1898 these workers made up 45 to 47 percent of the railroad employees in Iowa. By taking 46 percent of the earlier numbers of total railroad employees, I have estimated how many employees 
Lumping all workers together, as the commissioners did, the safest year during the 1880 s was 1880 , during which they concluded that 0.2 percent of railroad workers were killed and 0.7 percent were injured. Disregarding track workers and office workers, however, 0.8 percent of at-risk employees died during the year, while 2.9 percent were injured. In 1882, the worst year of the 1880 s, the commissioners calculated that 0.5 percent were killed and 2.9 percent received injury. Removing office workers and track workers reveals a far riskier occupation. A stunning 2.1 percent of at-risk employees died and 11.6 percent were injured in accidents (see table).

These adjusted accident statistics help to explain the national outcry for railroad safety appliances in the early 1890s. When congressman Henry Cabot Lodge compared the mortality rates of railroad workers and soldiers, he examined national statistics concerning the number of trainmen who died or were injured in the line of duty during 1889. Lodge's statistics more closely resemble the percentage of railroad employees killed and injured in Iowa during 1889 when office clerks and trackmen are removed from the total. In 1889, 7.2 percent of Iowa atrisk employees sustained injury, while the national number of trainmen injured was 8.3 percent. While Iowa's injury rate was slightly lower than the national average, the commission underreported the numbers of injured railroad workers for 1889 by at least 5.4 percent.

were at risk and what percentage of those employees were actually injured or killed. This method of statistical backtracking poses some risks. Perhaps there were fewer bureaucrats and more track workers during the 1870s than in the 1890 s. It is more likely, however, that the figure of 46 percent still exaggerates the number of employees exposed to danger, and thus underestimates the percentage of at-risk workers injured or killed. The commissioners, for example, lumped switchmen, flagmen, and watchmen together, even though being a switchman was far more hazardous than being a watchman or flagman. In addition, the commission included the nebulous category of "other track men," which accounted for about 20 percent of at-risk workers. Injuries on work trains were frequent, but it is difficult to determine what other trackrelated jobs may have been lumped under this category. Eliminating the category "other track men" would leave about 25 percent of workers susceptible to the majority of work-related injuries and deaths. I have decided to err on the side of generosity; the numbers that follow may be somewhat low. 


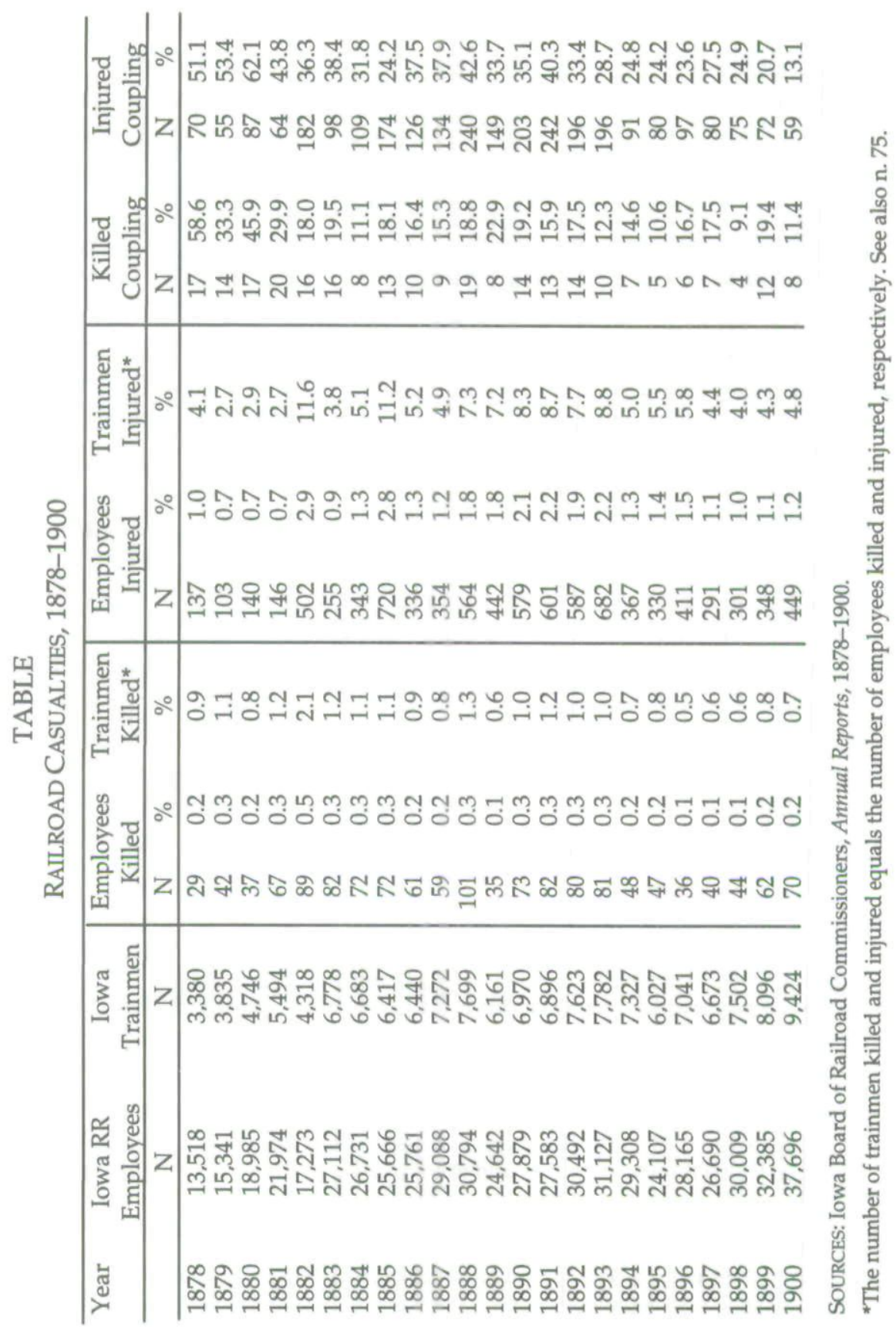


Iowa's railroad commissioners did not intentionally mislead their readers, but their smaller numbers did soften the bleak outlook for Iowa railroaders. The fault was not theirs alone. They did not collect their own data. According to commissioner Lorenzo Coffin, it was "not the custom ... of the Commission ... to investigate the maiming or the killing of a trainman. ${ }^{176}$ Instead, commissioners relied on railroad companies to state the number of workers employed in Iowa and to report serious accidents. Because the commission never issued guidelines describing what should be reportable and which accidents might be considered serious, railroad companies probably only reported accidents that involved equipment damage." Although Edward Laughlin's accident occurred a decade before the commission was created, it is unlikely that the IC would even have reported it-remember that the railroad contended that he had not sustained a serious injury.

Although impartial accident statistics were yet another casualty of the corporate drive to evade liability, the more modest published figures were still sufficiently shocking to spark public debate on railroad safety. When it became clear that railroad commissions and state legislatures would not demand or implement safety regulation, railroad brotherhoods and interested private citizens began to lobby for safety nationwide. In 1889 , for example, more than ten thousand members of the Brotherhood of Railroad Brakemen signed a petition in favor of rail-

76. Coffin, "Safety Appliances on the Railroads," 561.

77. This continued to be a national problem until Congress passed legislation on March 3, 1901, that required railroad companies to make detailed, monthly accident reports to the Interstate Commerce Commission. I. L. Sharfman, The Interstate Commerce Commission: A Study in Administrative Law and Procedure, part one (New York, 1931), 256-57; Interstate Commerce Commission, Accident Bulletin, No. 1, Showing Collisions and Derailments of Trains, and Casualties to Persons, during July, August, and September, 1901 (Washington, DC, 1902), 9. H. R. Fuller, lobbyist for the railroad brotherhoods, successfully argued that previous accident reporting standards that relied on overly broad descriptive categories misrepresented the causes of employee accidents. U.S. Congress, Senate, Subcommittee on Interstate Commerce, Testimony of $H$. R. Fuller, Legislative Representative of the Brotherhood of Locomotive Engineers, Brotherhood of Locomotive Firemen, Order of Railway Conductors, Brotherhood of Railroad Trainmen, and Order of Railroad Telegraphers, on the Bill (S. 3604) to Amend an Act to Promote the Safety of Employees, etc., 56th Cong., 2d sess., 23 April 1900, 1-2. 
road safety legislation and sent it to the ICC. ${ }^{78}$ BLE members also strongly supported legislative action to compel railroad companies to install safety devices.

Iowa railroad commissioner Lorenzo Coffin emerged as the most vocal advocate for workers' interests in the state. ${ }^{79} \mathrm{~A}$ devout man, zealous reformer, and prosperous farmer from Fort Dodge, Iowa, Coffin was appointed commissioner by Governor John Sherman in 1883. As a commissioner, Coffin's humanitarianism made him more interested in safety problems than in shipping rates-much to the irritation of his fellow commissioners. ${ }^{80}$ With the full endorsement of the state's trainmen, Coffin successfully lobbied the Iowa legislature to pass the Iowa Safety Appliance Act in 1890. The act mandated that all newly repaired railroad cars had to be equipped with safety or automatic couplers. After January 1, 1895, all cars used in Iowa would have to be fitted with safer couplers. Finally, by January 1893, Iowa trains had to have enough cars with air brakes installed to allow the engineer to stop the train from the locomotive. ${ }^{81}$

Workers throughout the nation hoped that the Iowa law would provide a model for national action. ${ }^{82}$ Again, Coffin was an indefatigable ally. He wrote hundreds of letters to brotherhood journals, "galvaniz[ing] the railroad unions to become active in the drive for national legislation. ${ }^{183}$ By 1892, Coffin represented the Brotherhood of Railroad Trainmen and the Order of Railway Conductors in meetings with the U.S. Railroad Commissioners. ${ }^{84}$ Coffin also strove to eliminate the divisions among the various brotherhoods that he thought might hamper the cause. He reminded engineers, for example, that the

78. Usselman, "Air Brakes for Freight Trains," 47.

79. For a firsthand account of Coffin's activities, see Coffin, "Safety Appliances on the Railroads."

80. Clark, "Railroad Safety Movement," 283-86.

81. IBRC, Report, 1890 (Des Moines, 1891), 7-8.

82. See, for example, Locomotive Engineers' Monthly Journal 24 (1890), 797.

83. Aldrich, Safety First, 33.

84. The former Brotherhood of Railroad Brakemen had changed its name to the Brotherhood of Railroad Trainmen in 1890. For more on the meeting of Coffin and the U.S. Railroad Commissioners, see Locomotive Engineers' Monthly Journal 26 (1892), 157. 
real enemies were the railroad owners who allowed the killing of brakemen to become so common that "the public have come to think it an inseparable part of railroad transportation. ${ }^{185} \mathrm{He}$ urged BLE members to write their congressmen and senators in support of the railroad safety legislation then being debated in Congress. ${ }^{86}$ After years of pressure from citizen groups and trainmen's organizations, Congress passed the Safety Appliance Act in $1893 .^{87}$ Railroad companies had seven years to bring interstate cars up to code.

It is hard to overstate the importance of the railroad safety movement for Iowa's railroaders. First and foremost, it dramatically, albeit gradually, reduced injuries, especially among men who coupled cars. More than half of all injuries to Iowa trainmen in 1878 had been due to coupler mishaps (see table); in 1901, the year after the national act took full effect, coupling accidents accounted for only 8.2 percent of all injuries. Iowa's rail lines had made little effort to install safety equipment on their own; the combination of state and national acts, though erratically enforced, had the cumulative effect of creating a safer workplace.

Moreover, the safety movement marked the beginning of a transformation in the relationships among corporate owners, workers, and the state. In an earlier period, the brotherhoods had attempted to claim that railroad officers and workers were equals engaged in a common enterprise. BLE leaders especially had perceived strikes as a measure of last resort, an unpleasant period of readjustment in an otherwise productive relationship. Railroaders, meanwhile, perceived the state as labor's adversary. As the business and legal climate changed, however, it became increasingly difficult to maintain the fiction that labor and management held similar bargaining power and shared a common interest in the trainman's welfare. Workers began to seek out state regulation and mediation on issues such as safety. The state, for its part, began to assert its authority to control aspects of private enterprise with a portion of the enthusiasm that it had previously reserved for the control of the nation's workers.

85. Ibid. 23 (1889), 987.

86. Ibid. 26 (1892), 262.

87. See Coffin, "Safety Appliances on the Railroads." 
DESPITE IMPROVING CONDITIONS, railroaders realized that they could not rely solely on the legal machinery of the state to right the balance between workers and employers. They never gave up their attack on the legal barriers of the doctrines of the fellow servant and of contributory negligence, nor did they assume that the terms of the Safety Appliance Act would be enforced without continual agitation. Even as the tide of injury turned, however, trainmen took steps to care for some of the thousands of already gravely injured men whom they assumed would be ignored by companies and the state.

To do so, brotherhoods joined with private citizens to sponsor homes for disabled trainmen, such as the Highland Park Home in Highland Park, Illinois. ${ }^{88}$ Some trainmen believed that such a home, centrally located and modestly funded by all brotherhoods, was sufficient. Others insisted that each brotherhood had a duty to serve its own members exclusively. As members vehemently debated the appropriate brotherhood response to the widespread problem of occupational disability, trainmen were forced to review their ideas about masculinity, risk management, and individual responsibility. In envisioning how they would care for their broken brothers, the brotherhoods defined the extent of their fraternal responsibilities to each other.

The BLE debates over care for the disabled illustrate broader trends in the brotherhoods. During most of the 1890s, BLE members argued over the establishment of a home for disabled engineers on a piece of BLE-owned farm property in Mattoon, Illinois, known as Meadow Lawn. One vocal group, hearkening back to notions that the disabled man was inherently less moral than the able-bodied, argued that unscrupulous engineers would feign a career-ending disability to get free care and food. This group insisted, moreover, that trainmen who practiced the ideals of railroad manhood would spurn charitable care. BLE member Cyrus E. Gallatin scorned those brotherhood men "who will not work in bad weather if they can avoid it; who will not deny themselves anything they can get, and are decid-

88. Lorenzo Coffin served as president of this first national home for disabled trainmen, established in 1890. Its official name was the Railroad Employees' Home. 
edly improvident." It was such men, Gallatin implied, who were most likely to become disabled in the first place. He strongly objected to the creation of the Meadow Lawn Home, insisting that it "would compel members who are industrious and provident to provide a luxurious home for the shiftless and improvident." Brother J. B. M. was even more blunt, accusing the proposed home of providing a refuge for "engineers who have spent their earnings at gaming tables, saloons, and worse places." The hostility toward the disabled, when coupled with comments about unscrupulousness and moral worth, suggests that some BLE members still believed that injuries resulted from incompetence and bad character. ${ }^{89}$

Another set of critics feared that Meadow Lawn would displace men from their rightful place as heads of their own households, thereby further eroding the disabled worker's claim to full masculinity. Supporters of Meadow Lawn, however, insisted that such would not be the case. T. H. Hiner proposed that Meadow Lawn set up single-unit housing so that families could live together. Such a family-centered approach, he explained, would make Meadow Lawn superior to other fraternal homes. "Do you, my Brother, want to go to a fraternal home somewhere, perhaps where you may never see the good, loving wife or dear children again; or would you rather go to the Meadow Lawn Home, where you can all be together, . . . a happy, unbroken family still?" Hiner drove home his point by comparing the proposed family-friendly environment of Meadow Lawn with the men-only care provided by the Highland Park Home, where "families must be separated, and while the husband is enjoying the comforts of that home, the good wife may be starving."

Many members agreed that broken men need not also have broken families, but resisted what they perceived as the replacement of the natal family with a "brotherhood family." They complained that the BLE should not usurp the duties of railroading families to provide care for elderly and disabled relatives. Indeed, trainmen who opposed the home argued that old

89. Locomotive Engineers' Monthly Journal 34 (1900), 294, 295.

90. Ibid., 101. 
and disabled engineers would not want to leave the support of their friends and family to live among strangers. One engineer explained, "Nothing on earth would tempt me to go to any home that would deprive me of my visits to my dear ones' graves." According to such BLE members, a man- even a disabled man -would be diminished if removed from the context of his own home. In their vision of brotherhood, members' fraternal duties to one another were strictly limited to workplace concerns. ${ }^{91}$

Most correspondents hoped that if Meadow Lawn became a reality, it would serve as only a temporary retraining center, quickly moving men with disabilities from unmanly dependency to gainful employment. To that end, engineers constantly insisted that their disabled brothers should have a critical role in their own care and support. One engineer from Cincinnati suggested that the BLE build an industrial plant on the Meadow Lawn property to provide employment for brothers who were out of work "on account of their age or other disqualifications. ${ }^{192}$

Rehabilitation to economic independence was only part of the injured man's remasculinization, however. Both to negate the common assumption that injured men had weak judgment and to assure potential residents that their manly prerogative to control their lives would not be denied them, Meadow Lawn supporters insisted that the disabled men would retain their independence. James Wood wrote that "everyone must be made to feel that they are at home, and not under iron rules, as would be the case in other institutions. ${ }^{\prime \prime 93}$ Brothers routinely feared that strict governance would undermine the independence of men who had considered themselves the indispensable leaders of the train crew.

91. Ibid., 104. Older engineers, such as Harry C. Smith, also worried about antagonizing younger BLE members. He explained, "The old fellows don't want a home where they know they are eating the bread of charity drawn from unwilling Brothers' pockets." It is unlikely, however, that all of Smith's older comrades would have agreed with his conclusion that "they would prefer the County [Poor] House, most likely." Ibid., 167.

92. Ibid., 35. Compare the Locomotive Firemen's Magazine 14 (1890), 705, which noted approvingly that the Miesse-Thorp Railway Brotherhood Hospital planned to use permanently disabled brotherhood men as male nurses.

93. Locomotive Engineers' Monthly Journal 34 (1900), 167. 
At the BLE's 1900 biennial convention held in Milwaukee, the matter was finally settled. Delegates agreed to sell Meadow Lawn Farm, and the idea of the Meadow Lawn Home died. One member concluded that the resolution "was a stroke of wisdom and common sense, and does away with a very annoying question. ${ }^{194}$ Correspondents, exhausted by a decade of debates, fell silent. In the year following the convention, not one letter attempted to revive the issue. ${ }^{95}$

Even the most hostile critics of brotherhood-centered care recognized that someone needed to tend to the most unfortunate in their ranks. They were less enthusiastic, however, about footing the bill. Iowa brotherhood locals supported a privately operated railroad employees' home in Highland Park, Illinois. Highland Park Secretary F. M. Ingalls happily told Iowa's conductors that the home's rehabilitation program was a success, bragging that two of the five residents of the home had left when they were able to "obtain situations by which they can earn their own livelihood, having learned their trades while inmates of the institution." Ingalls indicated, however, that some conductors doubted whether the benefits were worth the costs. Although Ingalls reassured members that he ran the home economically, he admitted that the home was "not a financial success." He then went on to chide the railroad brotherhoods for their failure to contribute more, especially in light of their swelling treasuries. "The great growth of the several organizations is apparent from their reports, and if one and all would do their part by contributing their mite we could build and maintain a 'Home' for the unfortunate railway man that would stand out before the world a monument of organized labor." ${ }^{\prime 96}$ Although Ingalls tried to remain optimistic, the fact remained that of the thousands of disabled railroaders in the Midwest alone, only five railroaders lived at Highland Park. After three years, the home had not captured much support from the brotherhoods.

94. Ibid. 35 (1901), 618.

95. Of course, it is possible that editor C. H. Salmons simply refused to print any further letters on the subject.

96. Railway Conductor 10 (1893), 25. The ORC was based in Cedar Rap ds. 
Highland Park officers realized that acceptance would take time. In 1893 Lorenzo Coffin, national railroad safety advocate and president of the home, commented, "It is a work of time and patience, to educate men up to the proper point of caring for a fellow and brother railway man." Coffin tried to elicit support by giving residential care a human face. He mentioned inmates by name, asking trainmen to consider what would happen if the home closed.

Shall this old engineer, Mr. Fish, now eighty-four years old; shall this conductor, Mr. Bangs, perfectly helpless; shall this fireman, Mr. Nace, with one leg; shall these helpless and suffering crippled men be turned upon the cold charity of the world, only to find their way, eventually, to the county poorhouse; from which we took our first inmate of the "Home," and who now is making a good living at the jeweler's trade, which the "Home" enabled him to learn? Already has the "Home" rescued three grand young men from hopeless dependency to self-sustaining independence.

Coffin stressed the dual goal of rehabilitation and manly reinvigoration. Although he equated disability with "hopeless dependency," he also viewed dependency as a temporary condition. The home would remake "men" of the disabled by restoring their earning capacity. Coffin recognized, however, that some trainmen were too disabled to return to the work force. In such cases, Coffin appealed to anxiety and self-interest to elicit contributions. "How soon some of these now contributing will be the suffering ones, none of us can tell. ${ }^{197}$

Although Frank Ingalls claimed that Highland Park was a success despite having only three permanent residents, his February 1893 quarterly report to the BLE's monthly journal indicates that engineers were once again wavering in their support of men with disabilities. At one point, the BLE voted to recognize the home only if it managed to get the endorsement of all eleven BLE divisions within Chicago. Coming at the height of the Meadow Lawn debate, this withdrawal of support must have been a blow to Highland Park organizers. As the BLE gave up on Meadow Lawn, however, divisions did send more dis-

97. Ibid., (1893), 100, 101. 
abled members to the Highland Park Home. In 1900 Highland Park housed twenty residents; seven of them were engineers. ${ }^{98}$

By 1900, all of the brotherhoods, the brotherhoods' ladies auxiliaries, and the ladies auxiliary to the Railroad YMCA supported Highland Park. ${ }^{99}$ Voluntary donations from the brotherhoods, however, meant seasonal fluctuations in generosity. Highland Park suffered from donation patterns that still plague charitable institutions. Donations increased during the holiday season, then declined thereafter. Lorenzo Coffin's dedication to the home project was readily apparent when he loaned the home \$250 and gave it "two fine shoats" to help make ends meet during the lean summer months. ${ }^{100}$

Coffin's frustration over the brotherhoods' intermittent interest in and inconsistent funding of care for their own members was evident. He began one angry letter by denouncing those who would deny the costly realities of disability: "Why can not men understand? Or do they understand, and are they thoughtless and a little mean?" Coffin huffed that brotherhood locals were more than willing to shuffle off their disabled men to the Home but refused to donate money to sustain its work. ${ }^{101}$

The chronic underfunding of the Highland Park Home suggests railroad workers' continuing ambivalence toward their disabled comrades. In a changing atmosphere of state intervention and increased corporate control of the workplace, the able-bodied reckoned anew with their assumptions about occupational disability, manhood, and the nature of their brotherly obligations to each other. Should they commit themselves to an ever-increasing collectivity in all things or should they vigorously defend their manly prerogative to control their homes, families, and bodies even if they could no longer control their workplace? Their debates over the character and needs of the

98. Ibid., 187; Locomotive Engineers' Monthly Journal 34 (1900), 176.

99. Highland Park was even well known enough to receive donations from individuals and groups not directly associated with railroad organizations. In November 1899 a group from Fort Worth, Texas, describing itself as "families and friends of railroad people," donated money and a box of groceries to the home. Locomotive Engineers' Monthly Journal 34 (1900), 35.

100. Ibid., 35, 111, 357, 577 .

101. Ibid. 30 (1896), 757. 
disabled, like their wavering support for their injured comrades, reveal that trainmen were not yet ready to abandon an individualistic notion of masculine rights and responsibility in favor of a more fraternalistic conception. Although they were willing to recognize the need for care for those with serious disabilities, they hesitated to commit themselves to an overarching fraternal vision that would have transcended individual responsibility and family-centered care.

EARLY IN THE NOVEL that gave the Gilded Age its name, a calamitous boiler explosion destroys a steamboat, killing at least a hundred people. A jury of inquest returns "the inevitable American verdict ... NOBODY TO BLAME. ${ }^{102}$ The anecdote, based on a true story, captures the state of the popular imagination concerning workplace safety during the late nineteenth century. Despite abundant evidence to the contrary, many people (trainmen included) persisted in believing that the hazards of the workplace were either unavoidable or that workers alone bore the responsibility for protecting themselves from harm. The idea that employers were best positioned to alleviate workplace danger and probably would not do so voluntarily was an idea slow to develop in American society.

During the Gilded Age, railroads chose to pursue profits over the safety of their work force. They could do so because legislators and jurists hesitated to interfere with private enterprise. This context helps to account for delayed implementation of safety technologies in the workplace and corporate evasion of legal liability for occupational disability. While such conditions hampered the efforts of Iowa trainmen to address the dangers of their workplace, they are not the whole story. To explain fully the processes that led to changes in workplace relations and the treatment of disabled workers, one must also consider the workers themselves. Trainmen initially believed that risk successfully flaunted was the measure of the true railroader and man, and skillful disregard of danger reflected competence. These attitudes changed, however, as the scale of the problem of

102. Mark Twain and Charles Dudley Warner, The Gilded Age: A Tale of Today, 2d ed. (1873; reprint, New York, 1994), 48. 
danger and disability became apparent during the 1880s. Courts were slow to perceive what workers and managers already knew: the impersonal rationalization of industrial capitalism had altered the face-to-face relationship between employers and employees that veteran trainmen, who had begun their careers when railroads themselves were new, had learned to expect in the early days of railroading.

This transitional period encompassed a complex set of interwoven issues. The rapid growth of American industry during the Gilded Age placed excessive demands on the nation's railroads. Increased rail traffic and a faster pace of work increased the number of accidents. Injuries mounted as volatile economic conditions made railroad companies unwilling to cope with even limited financial demands from their injured workers. When corporations attempted to rationalize their policies on safety and worker compensation, workers perceived that the proposed solutions violated long-held understandings about workplace control. Moreover, the solutions struck at the roots of working-class masculine ideology. Working men were to be denied both the right to make their own decisions in the workplace and the ability to see themselves as equal partners in the labor-management relationship. They could no longer sustain the illusion that they controlled their economic or physical destinies, nor could they be sure that they could provide for their families or protect them from want. ${ }^{103}$

103. Working-class ideals of manhood did not accurately reflect the realities of working-class family life. Although men saw themselves as the stable centers of economic activity and used their assumed position as "head of household" to argue for a higher "family wage," many families survived only because of the economic activities of other household members. See Christine Stansell, City of Women: Sex and Class in New York, 1789-1860 (Urbana and Chicago, 1986); Jeanne Boydston, Home and Work: Housework, Wages, and the Ideology of Labor in the Early Republic (New York, 1990); Alice Kessler-Harris, Out to Work: A History of Wage-Earning Women in the United States (New York, 1982); and Kathy Peiss, Cheap Amusements: Working Women and Leisure in Turn-of-theCentury New York (Philadelphia, 1986). It is unwise, moreover, to assume that class-based ideals of manhood evolve solely in the context of the workplace. See Kessler-Harris, "Treating the Male as 'Other." See also John WilliamsSearle, "Broken Brotherhood: Disability, Manliness, and Safety on the Rails, 1868-1908" (Ph.D. diss., University of Iowa, forthcoming). 
Although trainmen's debates over safety and disability during the Gilded Age indicate that the idea of a risk-filled individualistic manliness was slow to change, railroad brotherhoods finally began to demand federal laws to require railroads to install safety appliances. The industrial excesses of the Gilded Age prompted trainmen to demand a new relationship between themselves and the state. In Iowa industrial safety was an issue that revealed their efforts to create a new relationship between citizen-workers and the government; the Safety Appliance Act was one result. But, as trainmen soon discovered, the state was an imperfect ally.

Despite technological improvements, increased legal protections, and more rational attitudes toward risk-taking, trainmen remained skeptical about the state of safety on Iowa railroads. In 1905 the Iowa Bureau of Labor Statistics asked workers, "What specific legislation would benefit wage earners in your occupation?" Iowa railroaders replied by demanding greater attention to safety issues. Judging from their responses, Iowa railroaders felt that lack of enforcement and meaningful penalties for violation undermined the effectiveness of the Safety Appliance Act. A brakeman from Council Bluffs commented, "We need better enforcement of the safety appliance laws, also the enactment of an employer's liability law that will force railways to take care of the cripples they make." Other trainmen, such as locomotive engineers and switchmen, echoed those sentiments, with a switchman from Shenandoah concluding, "The enforcement of the present safety appliance law is the most needed at present. ${ }^{\prime 104}$ While demanding more federal regulation and better enforcement, the railroad brotherhoods also saw the need for worker-centered responses to help mend the broken bodies that industrial capitalism continued to produce. The very tentativeness with which trainmen embraced the notion of fraternal care for the disabled, however, demonstrates a resistance to the gradual reconfiguration of masculine identity in the rail trades.

103. Iowa Bureau of Labor Statistics, Twelfth Report . . . for the Year 1905 (Des Moines, 1907), 188, 189, 193. 
After decades of trivializing the risks of their occupation and scorning men who were injured on the job, Iowa trainmen were finally ready to admit the dangerous atmosphere in which they labored. Moreover, they seemed more willing to criticize their employers for creating and sustaining conditions in which accidents were all too common. A spirit of confrontation, absent in the days of brotherhood-company collaboration, began to emerge as workers turned to the courts, the U.S. Congress, state legislatures, and the workplace itself to make their lives more secure. Able-bodied men still had a long way to go before the new commitment to safety would be accompanied by a transformed attitude toward the disabled workers among them. It would take time to mend the broken brotherhoods. 
Copyright of Annals of Iowa is the property of State of Iowa, by \& through the State Historical Society of Iowa and its content may not be copied or emailed to multiple sites or posted to a listserv without the copyright holder's express written permission. However, users may print, download, or email articles for individual use. 